\title{
EXTENDING THE LIMITS OF CAMPOS RUPESTRES IN BRAZIL
}

Rubens Teixeira de Queiroz

Universidade Federal da Paraíba (UFPB), Departamento de Ecologia, João Pessoa, PB, Brasil rbotanico@gmail.com

Bartolomeu Israel de Souza

Universidade Federal da Paraíba (UFPB), Departamento de Geociências, João Pessoa, PB, Brasil bartolomeuisrael@gmail.com

José João Lelis Leal de Souza

Universidade Federal de Viçosa (UFV), Departamento de Solos, Viçosa, MG, Brasil

iilelis@ufv.br

Universidade Federal da Paraíba (UFPB), Departamento de Geociêncilsom Ramos de Medeiros .joseilsom.ramos@gmail.com

Christianne Farias da Fonseca

Universidade Federal da Paraíba (UFPB), Departamento de Geociências, João Pessoa, PB, Brasil chrisfariasdafonseca@gmail.com

Eini Celly Morais Cardoso

Universidade Federal da Paraíba (UFPB), Departamento de Geociências, João Pessoa, PB, Brasil einicelly@gmail.com

\begin{abstract}
Campos rupestres are typical ecosystems of rock outcrops with high biodiversity and endemism, located in Brazilian territory, with vegetation analogous in Africa and Australia. The Campos Rupestres cover deeply dystrophic soils on highlands inserted in Amazon rainforest, Atlantic rainforest, and Cerrado biomes. Despite recognition of Campos Rupestres as a global biodiversity hotspot, little is known its occurrence in dry forests. So this work aimed to describe vegetable cover and soil properties in highlands associated to rock outcrops on Caatinga biome. A pristine area in Borborema plateau was chosen as study area. Frequency of species and life forms indicate high vegetable density and herbaceous habits predominance. Although the high similarity of species with Caatinga biome, presence of Albizia, Dalbergia, Poecilanthe e Platymisciumindicates a truly distinct floristic composition. Soils are shallower, less fertile and has lower water storage capacity than predominant soils in Caatinga. This work reveals the presence of Campos Rupestres beyond the areas previously considered favorable to its presence, extending its occurre nce to regions of lower precipitation. The occurrence of the Campos Rupestres is attributed to an additional supply of water from fog in consonance with organic soils. Therefore, areas with similar characteristics should be prioritized to be preserved.
\end{abstract}

Keywords: Semiarid climate. Dry florests. Borborema province. Edaphology. Umbrisols. Water storage capacity.

\section{EXTENDENDO OS LIMITES DOS CAMPOS RUPESTRES NO BRASIL}

\section{RESUMO}

Campos rupestres são ecossistemas típicos de afloramentos rochosos com alta biodiversidade e endemismo, localizados no território brasileiro, com vegetação análoga na África e Austrália. Os Campos Rupestres cobrem solos profundamente distróficos em terras altas inseridas nas florestas da Amazônia, Mata Atlântica e biomas do Cerrado. Apesar do reconhecimento dos Campos Rupestres como hotspot da biodiversidade global, po uco se sabe sobre sua ocorrência em florestas secas. Assim, este trabalho teve como objetivo descrever a cobertura vegetal e as propriedades do solo em terras altas associadas a afloramentos rochosos no bioma Caatinga. Uma área intocada no planalto de Borborema foi escolhida como área de estudo. A frequência de espécies e formas de vida indica alta densidade vegetal e predominância de hábitos herbáceos. Embora a alta similaridade de espécies com o bioma Caatinga, a presença de Albizia, Dalbergia, Poecilanthe e Platymiscium indica uma composição florística verdadeiramente distinta. Os solos são mais rasos, menos férteis e com menor capacidade de armazenamento de água do que os solos predominantes na Caatinga. A ocorrência dos Campos Rupestres é atribuída a um suprimento adicional de água do nevoeiro em consonância com solos orgânicos. Portanto, áreas com características semelhantes devem ser priorizadas para preservação.

Palavras-chave: Clima semiárido. Florestas secas. Província Borborema. Edafologia. Organossolos. Capacidade de armazenamento de água. 


\section{INTRODUCTION}

Campos Rupestres ("rocky fields") are Brazilian endemic neotropical azonal ecosystems known as predominantly herbaceous-shrub vegetation, with sparse trees up to two meters high. They occur as a mosaic of rocky archipelagos on cliffs, plateaus, and highlands inserted in a matrix of zonal biomes, similar to rocky fields in South Africa and Southeastern Australia (FIEDLER, 2015; MORELLATO; SILVEIRA, 2018). The Campos Rupestres has a high diversity and hosts several endemic genera, although they not rely exclusively on a combination of them (ALVES; KOLBEK, 2010) and share several plant species with surrounding biomes, as the Atlantic rainforest (SANTOS et al., 2015), the Cerrado (Brazilian savanna) (WEBERLING, 2008) or the Amazon rainforest biomes (DA COSTALIMA, 2018). Although classified as endemic to Brazil, similar vegetation occurs in eastern Bolivia (NEVES et al., 2018).

Altitude, climate, and soils are the abiotic factors commonly indicated as determinants in the spatial distribution of the Campos Rupestres (ALVES et al., 2014; SILVEIRA et al., 2016). Its occurrence is frequent in elevations above 900 meters above sea level (m.a.s.I.) and annual precipitation areas between 800 and $1,500 \mathrm{~mm}_{\text {year }}{ }^{-1}$, under the influence of orographic rain and fog. The soils are shallow, incipient, deficient in nutrients, acidic, gravel, and low water storage capacity (VASCONCELOS, 2011). Consequently, few plant species successfully occupy these areas, and endemism is high (BENITES et al., 2003; SILVA et al., 2004). The Campos Rupestres host more than 5,000 vascular plant species, representing $14 \%$ of the total plant diversity of Brazil in only $1 \%$ of the total area (SILVEIRA et al., 2016).

Caatinga (xeric shrubland) biome is a semiarid biome of the northeast of Brazil, which covers about $12 \%$ of the country's territory. Xerophytic, woody, thorny, and deciduous physiognomies dominate flat surfaces in a hot and dry climate since at least 14,000 years before present (DE QUEIROZ et al., 2017; SANTANNA NETO; GALVANI; VIEIRA, 2015). Borborema plateau is highlighted in the Caatinga biome due to its wetter climate favored by a mean altitude five times higher than the rest of the biome (KAYANO; ANDREOLI, 2009). Borborema plateau has an area of approximately 65,000 $\mathrm{km}^{2}$ and covers four states in Brazil. It is one of the most prominent features derived from Brasiliano orogenic systems affected by the Cretaceous uplift, as Serra do Mar uplift and the Mantiqueira range in Southeastern Brazil (SALGADO et al., 2015).

The highlands in Borborema province archive 1,200 m.a.s.l. and have poorly studied ecosystems variability (SANTOS et al. 2011), where unknown areas of Campos Rupestres may even be present. We believe that Campos Rupestres are straight related to edaphic characteristics and hypothesized that its spatial distribution is more extensive than actual limits and comprehends highlands in the Caatinga biome. A detailed description of these sites is fundamental to understanding semiarid ecological processes and conservative policy development.

\section{METHODOLOGY}

\section{Study area}

Onças Environmental Protected Area (OEPA) was chosen as the study area (Figure 1). OEPA has a total area of 36,000 ha and particular landscape diversity. Altitudes vary between 600 m.a.s.l., in the valleys, and 1,200 m.a.s.l., in cliffs associated with resistant rocks and horst-graben systems. The site is located at Borborema plateau, which shows slightly dissection and typical characteristics of erosional surfaces in arid and semiarid regions, such as cliffs and inselbergs developed in Proterozo ic granites/granitoids, playas, and pediments (Byran 1922; King 1953). Shallow and low weathered Leptsols (correlate to Neossolos Litólicos in the Brazilian Soil Classification System), Luvisols (Luvissolos), Inceptsols (Cambissolos), and Regosols (Neossolos Regolíticos) represent $65 \%$ of the area (SANTOS et al., 2011). 
Rubens Teixeira de Queiroz

Bartolomeu Israel de Souza José João Lelis Leal de Souza Joseilsom Ramos de Medeiros Christianne Farias da Fonseca

Figure 1 - Brazil: (a) Location of Caatinga biome, (b) highlands in Northeastern Brazil and (c) study area location, 2017.

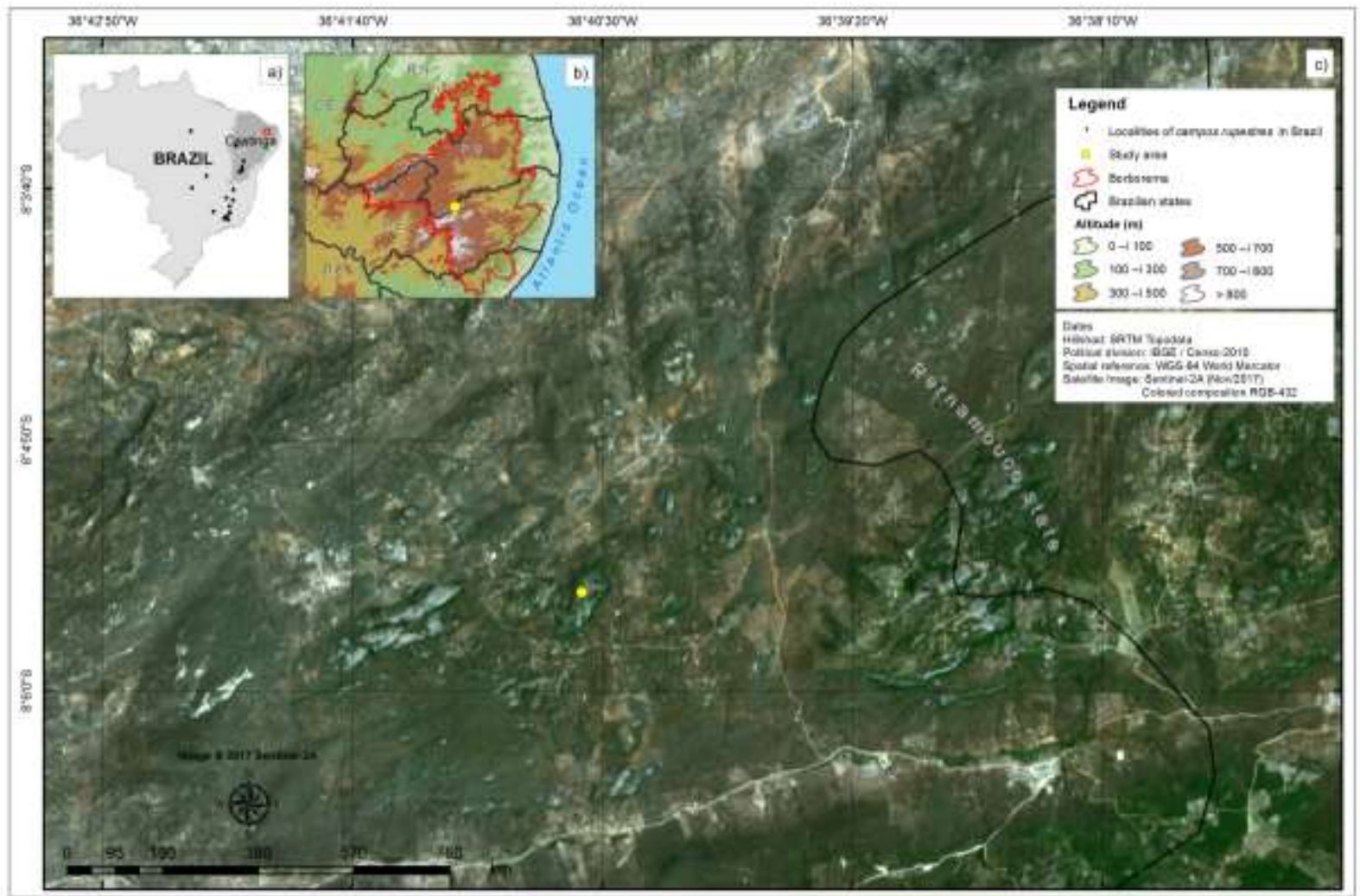

\section{Sampling and data analysis}

Precipitation, temperature, and humidity were measured between January 2017 and June 2018 by a Davis meteorological station in the study area. Although the data series is not sufficient to indicate the climate pattern of the site, we highlight that there is the first and the only meteorological station on a radio of $40 \mathrm{~km}$.

Habits, frequency, and vegetation species were identified by floristic surveys realized in representative sites of the study area between July and August 2018 (Supplemental material - Table). Photographic records of branches, leaves, inflorescences, flowers, fruits, and seeds were taken with a Nikon Coldpix P600 digital camera with a resolution of 16 megapixels to help identify and create a photographic record.

The identifications were made by consulting the relevant literature ("Reflora - Virtual Herbarium", 2018) and consultations with the specialists. The frequency of species was classified as: rare (1 to 5 individuals), frequent (6 to 10 individuals), or abundant (more than ten individuals). Life forms of plants were classified according to Raunkiaer (1934), and the geographical distribution of species was described according to literature.

One pedon was taken, described, and classified according to the World Reference Base soil classification system (IUSS WORKING GROUP WRB, 2014) to represent soil dominance in the site. Pedon also was classified according to the Brazilian Soil Classification System (SANTOS et al., 2018). Soil samples were collected from the surface down to the lithic contact.

According to methods established for tropical soils, samples were air-dried and sieved through a $2 \mathrm{~mm}$ sieve prior to texture and chemical analysis (DONAGEMA et al., 2011). Sand, silt, and clay were determined by the pipette method after dispersion with $0.1 \mathrm{M} \mathrm{NaOH}$. Soil $\mathrm{pH}$ was measured with a glass electrode in a 1:2.5 suspension v/v soil and deionized water $\left(\mathrm{H}_{2} \mathrm{O} \mathrm{pH}\right)$ and $1 \mathrm{M} \mathrm{KCl}$ solution $(\mathrm{KCl}$ 
Rubens Teixeira de Queiroz

Bartolomeu Israel de Souza José João Lelis Leal de Souza Joseilsom Ramos de Medeiros Christianne Farias da Fonseca Eini Celly Morais Cardoso

$\mathrm{pH})$. The potential acidity $(\mathrm{H}+\mathrm{Al})$ was extracted by $1 \mathrm{M}$ ammonium acetate solution at $\mathrm{pH}$. The content of exchangeable $\mathrm{Ca}^{2+}, \mathrm{Mg}^{2+}$, and $\mathrm{Al}^{3+}$ were determined in a $1 \mathrm{M} \mathrm{KCl}$ extract. Exchangeable $\mathrm{K}^{+}$ and $\mathrm{Na}^{+}$were determined after Melhich-1 extraction. From these results, the sum of bases (SB), base saturation $(\mathrm{V})$, aluminum saturation $(\mathrm{m})$, equivalent cation exchange capacity (ECEC), and total cation exchange capacity (CEC) were calculated.

The available phosphorus content (PM) was determined by a Mehlich-1 extraction solution. The soil organic carbon (SOC) was determined by wet combustion (YEOMANS; BREMNER, 1988). Total nitrogen (N) was determined by the Kjeldahl method and titration (EMBRAPA, 1997). The carbon to nitrogen ratio $(\mathrm{C} / \mathrm{N})$ was calculated on a mass basis. The $\mathrm{P}$ adsorption capacity of the soil was determined after stirring for 1 hour with $2.5 \mathrm{~g}$ of soil in $0.01 \mathrm{M} \mathrm{CaCl}_{2}$ containing $60 \mathrm{mg}$ of $\mathrm{P} \mathrm{L}^{-1}$. The suspension was filtered, and the remaining $P$ in solution (PREM) was determined by photocolorimetry (ALVAREZ et al., 2000).

Bulk density, particle density and water retention curve $(-6,-10,-30,-60,-100,-300,-1500 \mathrm{kPa}$ tensions) were determined in undisturbed soil samples collected by volumetric rings (EMBRAPA, 1997). Total porosity, available water, and non-available water were calculated from these results.

\section{RESULTS}

One hundred and forty-four species, distributed among fifty-two families, were identified and (Figure 2). One basal angiosperm (one sp.), two monilophytes (one sp. each one), nine monocotyledon and forty-one eudicotyledon were the major groups identified. Senna, Mimosa (4 sp. each one), Chamaecrista, Erythroxylum, Habenaria, Solanum e Tillandsia (3 spp.) were the genres most representative in the study area.

Figure 2 - Borborema province: Number of species of major families identified in study area, 2020.

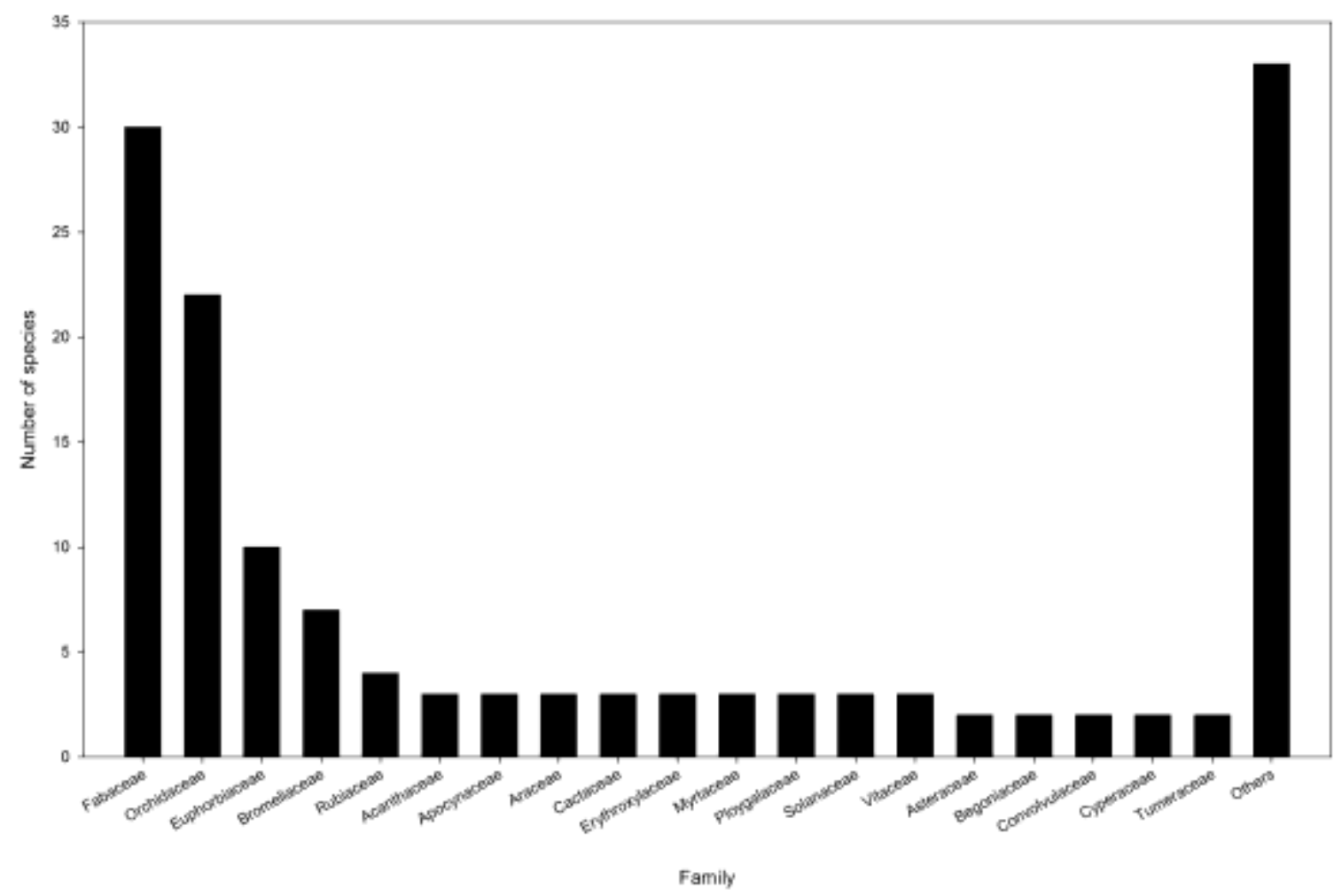


Thirty-nine percent $(n=53)$ and thirty-three percent $(n=45)$ of species are phanerophytes and chamaephytes, respectively (Supplemental material - Table). The majority of species have a frequency between 6 to 10 individuals, indicating a high vegetable density in the study area. Herbaceous habits predominate (57 species or $41.9 \%$ of total), followed by shrub habits (39 species or $28.7 \%$ ). Trees are dominantly short (between $0.25 \mathrm{~cm}$ to $5 \mathrm{~m}$ of height), with buds above the soil surface and protected from dehydration by cataphyll (VELOSO; RANGEL FILHO; LIMA, 1991).

Seventhly-six percent of total species are found in more than one Brazilian biome (Supplemental material - Table). Thirty-two species identified (23.5\% of total) are associated to other Brazilian biomes: Amazon rainforest $(2.78 \%)$, Atlantic rainforest $(18.05 \%)$, or Cerrado (Brazilian savanna) (2.67\%) ("Reflora - Virtual Herbarium", 2018).

Seventh percent of the precipitation is concentrated between February and July. Mean annual precipitation was $470.57 \mathrm{~mm}$ year ${ }^{-1}$, and mean monthly humidity is dominantly below $70 \%$. The annual temperature range is high, with maximum temperature $\left(30.4^{\circ} \mathrm{C}\right)$ measured in March and minimum $\left(15.4^{\circ} \mathrm{C}\right)$ in July; the mean temperature is $21.4^{\circ} \mathrm{C}$.

A Umbrisols (Organossolo, according to Brazilian System of Soil Classification) was described according to WRB in a summit of a slope, above 1,000 m.a.s.l., and associated with rock outcrops. Topsoil is classified as folic epipedon according to World Reference Soil Base.

The soil is composed of a sequence of $O$ and $A$ horizons above continuous rock (Table 1). The soil is shallow, and the transition between horizons was gradual and abrupt with the R layer. The soil color is black in umbric and folic epipedons. The structure is weakly developed, with granular type. The consistence of Umbrisols is soft, non-stick, and non-plastic.

Table 1 - Borborema province:Morphological properties of soil, 2020.

\begin{tabular}{llllllll}
\hline Horizon & $\begin{array}{l}\text { Depth } \\
(\mathrm{cm})\end{array}$ & $\begin{array}{l}\text { Boundary } \\
\text { (distinctness, } \\
\text { topography) }\end{array}$ & $\begin{array}{l}\text { Color } \\
\text { (moist, } \\
\text { dry) }\end{array}$ & $\begin{array}{l}\text { Structure } \\
\text { (grade, } \\
\text { size, type) }\end{array}$ & $\begin{array}{l}\text { Consistence } \\
\text { (dry, moist, } \\
\text { wetter, } \\
\text { cementation) }\end{array}$ & $\begin{array}{l}\text { Roots } \\
\text { (quantity, } \\
\text { size) }\end{array}$ & $\begin{array}{l}\text { Pores } \\
\text { (quantity, } \\
\text { size, } \\
\text { shape) }\end{array}$ \\
& & & & & & &
\end{tabular}

Epifolic Endoleptic Umbrisols (Pantoloamic, Pantohyperhumic)/ORGANOSSOLO FOLICO Sáprico lítico

$\begin{array}{lllll}0-10 \quad \text { G-S } & 5 Y 1 / 1, \quad 1, \mathrm{~m}, \mathrm{gr} & \mathrm{S}, \mathrm{FR}, \mathrm{so}, \mathrm{po}, \quad 3, \mathrm{f}-\mathrm{vf} & \text { 3C } \\ & 5 Y 2.5 / 1 & & \end{array}$

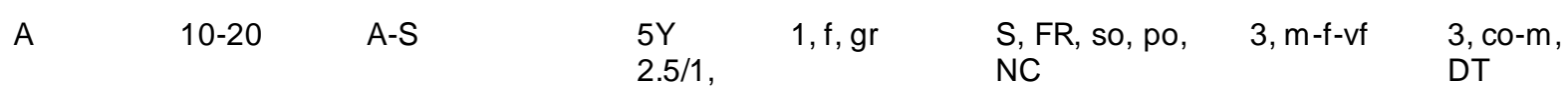

$5 Y 3 / 1$

R $\quad 20+$

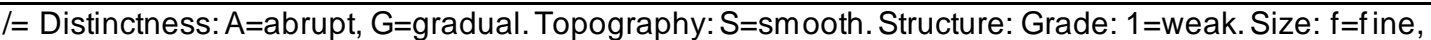
$\mathrm{m}=$ medium. Type: $g r=g r a n u l a r$. Consistence: Dry: $S=$ soft. Moist: $F R=$ friable. Wetter: po=nonplastic, so=nonsticky.

Cementation: $\mathrm{NC}=$ non-cemented. Roots and pores: $3=\mathrm{m}$ any, $\mathrm{co}=\mathrm{coarse}, \mathrm{f}=\mathrm{fine}, \mathrm{m}=\mathrm{medium}, \mathrm{DT}=$ dendritic tubular.

Roots are abundant, and their growth is limited by lithic contact. Fine and very fine roots are dominant in the soil profile. Medium roots occur above $10 \mathrm{~cm}$ of depth. Dendritic tubular pores are abundant, indicating widespread bioturbation. The soil profile is loam, and coarse sand is the main fraction of soil (Table 2). Umbrisol is extremely acid, dystrophic, $\mathrm{KCl} \mathrm{pH}$ is below 5.0 , and delta $\mathrm{pH}$ is negative in all horizons, indicating that negative charges dominate (Table 3). $\mathrm{Ca}^{2+}>\mathrm{Mg}^{2+}>\mathrm{K}^{+}>\mathrm{Na}^{+}$is the base dominance in the exchange complex. SB, CEC, $\mathrm{PM}, \mathrm{C}$, and $\mathrm{N}$ content decrease with the increase of depth. Values of $\mathrm{P}$-rem below $20 \mathrm{mg} \mathrm{L}^{-1}$ indicates a high $\mathrm{P}$ adsorption capacity by organic compounds. The $\mathrm{C} / \mathrm{N}$ ratio decreased with increasing depth, suggesting a lower degree of humification of organic residues at $10-20 \mathrm{~cm}$ depth.

Caminhos de Geografia $\quad$ Uberlândia-MG $\quad$ v. 22, n. $82 \quad$ ago./2021 $\quad$ p.115-137 Página 119


Table 2 - Borborema province:Physical soil properties, 2020.

\begin{tabular}{lllllll}
\hline & $\begin{array}{l}\text { Depth } \\
\text { Horizon }\end{array}$ & $\begin{array}{l}\text { Coarse } \\
\text { sand }\end{array}$ & $\begin{array}{l}\text { Fine } \\
\text { sand }\end{array}$ & Silt & Clay & \\
\multicolumn{2}{l}{$\begin{array}{l}\text { Epifolic Endoleptic Umbrisols (Pantoloamic, Pantohyperhumic)/ORGANOSSOLO FOLICO Sáprico } \\
\text { lítico }\end{array}$} \\
O & $0-10$ & 34.1 & 14.8 & 29.5 & 21.6 & loam \\
$\mathrm{A}$ & $10-20$ & 35.1 & 17.9 & 25.2 & 21.8 & gravelly-sandy clay loam \\
$\mathrm{R}$ & $20+$ & & & & & \\
\hline
\end{tabular}

Table 3 - Borborema province: Chemical soil properties of the study area and comparison data.

\begin{tabular}{|c|c|c|c|c|c|c|c|c|c|c|c|c|c|c|c|c|c|c|c|}
\hline $\begin{array}{l}\text { Ho } \\
\text { riz } \\
\text { on }\end{array}$ & $\begin{array}{l}\text { De } \\
\text { pth }\end{array}$ & $\begin{array}{l}\mathrm{H}_{2} \\
\mathrm{O} \\
\mathrm{pH}\end{array}$ & $\begin{array}{l}\text { KC } \\
\text { I } \\
\text { pH }\end{array}$ & $\mathbf{P}_{\mathbf{M}}$ & $\mathbf{K}^{+}$ & $\mathrm{Na}^{+}$ & $\begin{array}{l}\mathrm{Ca}^{2} \\
+\end{array}$ & $\begin{array}{l}\mathbf{M} \\
\mathbf{g}^{2} \\
+\end{array}$ & $\begin{array}{l}\mathbf{A l}^{3} \\
+\end{array}$ & $\begin{array}{l}\mathbf{H} \\
+ \\
\mathbf{A l}\end{array}$ & SB & $\begin{array}{l}E \\
C \\
E \\
C\end{array}$ & $\begin{array}{l}\mathbf{C} \\
\mathrm{E} \\
\mathrm{C}\end{array}$ & V & $\mathbf{m}$ & C & $\mathbf{N}$ & $\begin{array}{l}\mathbf{C} \\
/ \\
\mathbf{N}\end{array}$ & $\begin{array}{l}P_{R} \\
\text { EM }\end{array}$ \\
\hline & $\mathrm{cm}$ & & & $\mathrm{dm}^{-}$ & --- & & - & ----- & ---- & & 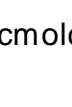 & $\mathrm{dm}$ & ---- & & & -- 9 & - & & $\begin{array}{l}\mathrm{m} \\
\mathrm{g} \\
\mathrm{L}^{-1}\end{array}$ \\
\hline
\end{tabular}

Epifolic Endoleptic Umbrisols (Pantoloamic,

Pantohyperhumic)/ORGANOSSOLO FÓLICO

Sáprico lítico

$\begin{array}{llllllllllllllllllllll} & 0 & 0 & 4.4 & 4.1 & 24 . & & & 39 & 39 . & 7.9 & 2 . & 0.1 & 16 & 10 . & 1 . & 27 & & & 1 & 1 & \\ & 10 & 6 & 4 & 7 & & 0 & 3 & 62 & 9 & .2 & 90 & 0 & .1 & 40 & 2 & 20 . & . & 7 & 20 \\ & & & & & & & & & & & & 9 & 0 & & & & 5 & 6 & .0\end{array}$

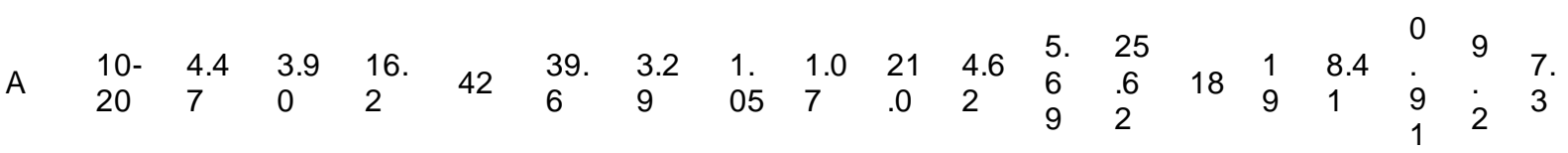

R $20+$

\begin{tabular}{|c|c|c|c|c|c|c|c|c|c|c|c|c|c|c|c|c|c|c|}
\hline \multicolumn{19}{|c|}{ Comparison data } \\
\hline BR & $\begin{array}{l}4.4 \\
0- \\
18\end{array}$ & - & $\begin{array}{l}5.0- \\
138\end{array}$ & - & - & - & - & $\begin{array}{l}3.4 \\
5- \\
15 \\
5\end{array}$ & $\begin{array}{l}30 \\
.2- \\
66\end{array}$ & $\begin{array}{l}7.2 \\
5- \\
13 \\
1\end{array}$ & - & $\begin{array}{l}44 \\
.8- \\
54\end{array}$ & $\begin{array}{l}16 \\
- \\
10 \\
0\end{array}$ & - & $\begin{array}{l}22 . \\
9- \\
53\end{array}$ & - & - & - \\
\hline PA & $\begin{array}{l}4.4 \\
0- \\
15\end{array}$ & $\begin{array}{l}3.2 \\
0- \\
18\end{array}$ & $\begin{array}{l}2.0- \\
25\end{array}$ & $\begin{array}{l}78- \\
18\end{array}$ & $\begin{array}{l}14 . \\
4-1\end{array}$ & $\begin{array}{l}1.0 \\
5- \\
47\end{array}$ & $\begin{array}{l}0 . \\
45 \\
- \\
16\end{array}$ & $\begin{array}{l}1.3 \\
0- \\
33\end{array}$ & $\begin{array}{l}21 \\
.5- \\
6\end{array}$ & $\begin{array}{l}1.7 \\
5- \\
28\end{array}$ & $\begin{array}{l}3 . \\
2 \\
0- \\
4\end{array}$ & $\begin{array}{l}23 \\
.2 \\
0- \\
8\end{array}$ & $\begin{array}{l}8- \\
20\end{array}$ & $\begin{array}{l}4 \\
6- \\
2 \\
6\end{array}$ & $\begin{array}{l}20 . \\
04 \\
- \\
23\end{array}$ & - & - & $\begin{array}{l}24 \\
.6- \\
23\end{array}$ \\
\hline PB & $\begin{array}{l}5.9 \\
0- \\
19\end{array}$ & $\begin{array}{l}4.8 \\
-20\end{array}$ & $\begin{array}{l}1.0- \\
360\end{array}$ & $\begin{array}{l}5- \\
100\end{array}$ & $\begin{array}{l}23- \\
321\end{array}$ & $\begin{array}{l}3.9- \\
121\end{array}$ & $\begin{array}{l}2 . \\
1- \\
11 \\
8\end{array}$ & $\begin{array}{l}0.1 \\
0- \\
15 \\
7\end{array}$ & $\begin{array}{l}1 . \\
3- \\
10 \\
0\end{array}$ & $\begin{array}{l}5.4 \\
- \\
12 \\
3\end{array}$ & $\begin{array}{l}6 . \\
6- \\
8 \\
7\end{array}$ & $\begin{array}{l}27 \\
.6- \\
99\end{array}$ & $\begin{array}{l}78 \\
- \\
48\end{array}$ & $\begin{array}{l}0- \\
1 \\
6 \\
1\end{array}$ & $\begin{array}{l}0.4 \\
- \\
89\end{array}$ & $\begin{array}{l}0 \\
0 \\
0 \\
5 \\
- \\
6 \\
3\end{array}$ & $\begin{array}{l}8 \\
0\end{array}$ & - \\
\hline
\end{tabular}

BR= Organic soil horizons in Brazil (Beutler and others 2017, $\mathrm{n}=280$ ); PA= campo rupestre soils in Pará

(Schaefer and others 2015, n=6); PB=Paraíba soils (EMBRAPA, 2017, n=327). 
The soil profile presented particle and bulk densities values close to the density of light fraction and weakly humified soil organic compounds (BARRIOS; BURESH; SPRENT, 1996; VASILINIUC; PATRICHE, 2015) (Table 4). Field capacity and available water represent approximately 60 and $27 \%$ of total porosity, respectively.

Table 4 - Physical soil properties determined in undisturbed samples.

\begin{tabular}{|c|c|c|c|c|c|c|c|}
\hline Horizon & $\begin{array}{l}\text { Depth } \\
\mathrm{cm}\end{array}$ & Particles density & Bulk density & $\begin{array}{l}\text { Total } \\
\text { porosity }\end{array}$ & $\begin{array}{l}\text { Field } \\
\text { capac } \\
\text { ity } \\
-\%\end{array}$ & $\begin{array}{l}\text { Availa } \\
\text { ble } \\
\text { water }\end{array}$ & $\begin{array}{l}\text { Wilti } \\
\text { ng } \\
\text { point }\end{array}$ \\
\hline \multicolumn{8}{|c|}{$\begin{array}{l}\text { Epifolic Endoleptic Umbrisols (Pantoloamic, Pantohyperhumic)/ } \\
\text { ORGANOSSOLO FÓLICO Sáprico lítico }\end{array}$} \\
\hline O & $0-10$ & 1.71 & 0.95 & 44.44 & 26.80 & 13.20 & 13.60 \\
\hline$A$ & $10-20$ & 1.77 & 0.95 & 46.33 & 26.70 & 12.30 & 14.40 \\
\hline$R$ & $20+$ & & & & & & \\
\hline
\end{tabular}

\section{DISCUSSION}

The presence of Albizia, Dalbergia, Poecilanthe and Platymiscium indicates a truly distinct floristic composition. Rocky outcrops have been cited as one of the most representative sites for Orchid aceae in Northeast Brazil (Rapini others 2008; Pessoa and Alves 2014). Orchidaceae is the family with the second-largest diversity in the study area, whereas it is composed of only a few species or even not present in Caatinga.

The dominance of Fabaceae and high similarity of species with Caatinga biome (CORDEIRO; SOUZA; FELIX, 2018; LUCENA et al., 2015; PEREIRA et al., 2018; SALES-RODRIGUES; BRASILEIRO; MELO, 2014) suggest that the composition of Campos Rupestres is highly influenced by distribution and connection of highlands, as well the heterogeneity of neighborhood ecosystems (ALVES; KOLBEK, 2010; NEVES et al., 2018; SILVEIRA et al., 2016). Besides that, species associated with neighborhood ecosystems showing a distinct physiognomy influenced by shallow dystrophic soils, high diurnal seasonality, and relief (ALVES et al., 2014; ALVES; CARDIN; KROPF, 2007; NEVES et al., 2018; VASCONCELOS, 2011).

The low fertility of the soil profile conditioned the development of survival strategies involving physiological and morphological adaptations (EITEN, 1983; SILVEIRA et al., 2016) (Supplemental material - Figures I to XI). Some nutrients, significantly $\mathrm{P}$, which is extremely limiting for plant development, show negligible amounts (Table 3).

The decrease of soil fertility with the increase in depth suggests that chemical soil properties are straight associated with organic residue input. So, biogeochemical cycling of nutrients in dystrophic soils seems essential for vegetation maintenance against leaching (DE SOUZA et al., 2018; LUCAS, 2001; MANZONI et al., 2010; SARCINELLI et al., 2013). The abundance of fine and very fine roots in soil profile reinforces this hypothesis (FERREIRA et al., 2018; HASENMUELLER and SCOTT, 2017).

The adaptive mechanisms of plants to hydric stress is attributed to low precipitation and low water availability in soils (Supplemental material - Figures I to XI). Annual precipitation in 2017 is $22 \%$ and until $70 \%$ lower than predicted precipitation (FUNK et al., 2015) and mean annual precipitation registered in Campos Rupestre sites around Brazil (ALVES et al., 2014), respectively. On the other hand, the high mean monthly humidity suggests high input of water no measured by meteorological station as the condensation of fog (Supplemental material - Figure XII).

In general, organic materials and soil horizons with high organic content have high water availability (BENITES et al., 2007; MINASNY; MCBRATNEY, 2018). However, the high wilting point indicates that less than $50 \%$ of water retained by soil is available for plants (Table 4 ). So, the soil seems to be essential to the genesis of the Campos Rupestres. Dystrophia and low water availability favor the occupation of species of more efficient nutrient uptake, reduced nutrient consumption, and efficient water storage. Improvements in nutrient uptake are facilitated by root adaptations such as nitrogen- 
fixing root nodules, mycorrhizae, and clustered roots (NOGUEIRA et al., 2005; OLIVEIRA et al., 2015). Consumption is reduced by very slow growth rates (MORELLATO; SILVEIRA, 2018) and the efficient use of low-availability nutrients (ATAÍDE; CASTRO; FERNANDES, 2011; BENZING, 1990a). Absorption and retention of water are complemented by roots and pseudobulbs that exploit fog (GUGLIERI; ZULOAGA; LONGHI-WAGNER, 2004) and reduce water vapor loss (BENZING, 1990b). The occurrence of species with these adaptive mechanisms in oligotrophic soils suggests climatic stability and should be investigated in future studies (SILVEIRA et al., 2016).

\section{CONCLUSION}

This work highlights the high heterogeneity of ecosystems that composes the Caatinga biome, establishing several phytophysiognomies (DE QUEIROZ et al., 2017; SILVA et al., 2014). Shrubs xerophilous vegetation on shallow eutrophic soils of flat and lowlands bellow 200 m.a.s.l. are replaced by semideciduous forests on plateaus which range in altitude from 500 to 750 m.a.s.I. (ARAÚJO FILHO et al., 2017; DOMBROSKI et al., 2011) This denser vegetation is favored by lower evapotranspiration, orographic rainfall, and more developed soils with higher potential for water storage (RIBEIRO et al., 2016; SCHULZ et al., 2016). The discovery of Campos Rupestres in the Caating a biome further elevates this heterogeneity and indicates the needy for researches in this part of Brazil, particularly those that integrate soil to ecological processes. The areas covered by rupestrian fields are highly sensitive and require special attention in the conservation strategies of biotic and abiotic resources that compose these ecosystems.

\section{REFERENCES}

ALVAREZ, V. H.; NOVAIS, R. F.; DIAS, L. E.; OLIVEIRA, J. A.. Determinação e uso do fósforo remanescente. Boletim Informativo da Sociedade Brasileira de Ciência do Solo, v. 25, n. 1, p. 2732, 2000.

ALVES, R.; SILVA, N. G.; OLIVEIRA, J. A.; MEDEIROS, D. Circumscribing campo rupestre megadiverse Brazilian rocky montane savanas. Brazilian Journal of Biology, v. 74, n. 2, p. 355-362, 2014. https://doi.org/10.1590/1519-6984.23212

ALVES, R. J. V.; CARDIN, L.; KROPF, M. S. Angiosperm disjunction "Campos rupestres - restingas": a re-evaluation. Acta bot. bras, v. 21, n. 3, p. 675-685, 2007. https://doi.org/10.1590/S010233062007000300014

ALVES, R. J. V.; KOLBEK, J. Can campo rupestre vegetation be floristically delimited based on vascular plant genera? Plant Ecology, v. 207, n. 1, p. 67-79, 2010. https://doi.org/10.1007/s11258$\underline{009-9654-8}$

ARAÚJO FILHO, J. C.; RIBEIRO, M. R.; BURGOS, N.; MARQUES, F. A. Solos da Caatinga. In: CURI, N. et al. (Eds.). . Pedologia - Solos dos Biomas Brasileiros. Viçosa-MG: Sociedade Brasileira de Ciência do Solo, 2017. p. 227-260.

ATAÍDE, E. S.; CASTRO, P. DE T. A.; FERNANDES, G. W. Florística e caracterização de uma área de campo ferruginoso no Complexo Minerário Alegria, Serra de Antônio Pereira, Ouro Preto, Minas Gerais, Brasil. Revista Árvore, v. 35, n. 6, p. 1265-1275, 2011. https://doi.org/10.1590/S010067622011000700013

BARRIOS, E.; BURESH, R. J.; SPRENT, J. I. Organic matter in soil particle size and density fractions from maize and legume cropping systems. Soil Biology and Biochemistry, v. 28, n. 2, p. 185-193, 1996. https://doi.org/10.1016/0038-0717(95)00110-7

BENITES, V. M.; SCHAEFER, C. E. G. R.; SIMAS, F. N. N.; SANTOS, H. G. Soils associated with rock outcrops in the Brazilian mountain ranges Mantiqueira and Espinhaço. Revista Brasileira de Botânica, v. 30, n. 4, p. 569-577, 2007. https://doi.org/10.1590/S0100-84042007000400003

BENZING, D. H. Mineral nutrition. In: Vascular epiphytes. Cambridge: Cambridge University Press, 
Rubens Teixeira de Queiroz

Bartolomeu Israel de Souza José João Lelis Leal de Souza Joseilsom Ramos de Medeiros Christianne Farias da Fonseca

1990a. p. 112-151. https://doi.org/10.1017/CBO9780511525438.006

BENZING, D. H. Water balance. In: Vascular epiphytes. Cambridge: Cambridge University Press, 1990b. p. 80-111. https://doi.org/10.1017/CBO9780511525438.005

BEUTLER, S. J.; PEREIRA, M. G.; TASSINARI, W. S.; MENEZES, M. D.; VALLADARES, G. S.; ANJOS, L. H. C. Bulk density prediction for histosols and soil horizons with high organic matter content. Revista Brasileira de Ciencia do Solo, v. 41, p. 1-13, 2017. https://doi.org/10.1590/18069657rbcs20160158

CORDEIRO, J. M. P.; SOUZA, B. I.; FELIX, L. P. Levantamento florístico em afloramento rochoso no piemonte da Borborema, Paraíba, Brasil. GEOSUL, v. 33, n. 67, p. 214-228, 2018. https://doi.org/10.5007/2177-5230.2018v33n67p214

DA COSTA-LIMA, J. L. Flora das cangas da serra dos carajás, pará, brasil: Rhizophoraceae. Rodriguesia, v. 69, n. 1, p. 205-207, 2018. https://doi.org/10.1590/2175-7860201869118

DE QUEIROZ, L. P.; LEAL, I.; TABARELLI, M. Diversity and Evolution of Flowering Plants of the Caatinga Domain. In: Caatinga. Cham: Springer International Publishing, 2017. p. 23-63. https://doi.org/10.1007/978-3-319-68339-3 2

DE SOUZA, J. J. L. L.; FONTES, M. P. F.; GILKES, R.; COSTA, L. M.; OLIVEIRA, T. S.; Geochemical Signature of Amazon Tropical Rainforest Soils. Revista Brasileira de Ciência do Solo, p. 1-18, 2018. https://doi.org/10.1590/18069657rbcs20170192

DOMBROSKI, J. L. D.; PRAXEDES, S. C.; FREITAS, R. M. O.; PONTES, F. M. Water relations of Caatinga trees in the dry season. South African Journal of Botany, v. 77, n. 2, p. 430-434, 2011. https://doi.org/10.1016/j.sajb.2010.11.001

DONAGEMA, G. K.; CAMPOS, D. B. V.; CALDERANO, S. B.; TEIXEIRA, W. G.; VIANA, J. H. Manual de métodos de análise de solos. 2. ed. Rio de Janeiro: Embrapa Solos, 2011.

EITEN, G. Classificação da vegetação do Brasil. Brasília: CNPq/Coordenação Editorial, 1983.

EMBRAPA. Manual de métodos de análises de solos. [s.I.] Embrapa, 1997.

FERREIRA, G. W. D.; CAPARELLI, F. C.; SILVA, L. G. O.; SOUZA, J. J. L. L.; SOARES, M.; ARAUJO, E. F.; RIBEIRO, I. Nitrogen alters initial growth, fine-root biomass and soil organic matter properties of a Eucalyptus dunnii Maiden plantation in a recently afforested grassland in southern Brazil. Forests, v. 9, n. 2, p. 1-14, 2018. https://doi.org/10.3390/f9020062

FIEDLER, P. L. The Fascinating Ecology of Two Megadiverse Southern Hemisphere EcosystemsPlant Life on the Sandplains in Southwest Australia. LambersH., editor. 2014. University of Western Australia Press, Perth, Australia. 350 pp. $\$ 69.99$ (hardcover). ISBN 13-98717425856. Conservation Biology, v. 29, n. 6, p. 1727-1729, 2015. https://doi.org/10.1111/cobi.12624

FUNK, C.; PETERSON, P.; LANDSFELD, M.; PEDREROS, D.; VERDIN, J.; SHUKLA, S.; HUSAK, G.; ROWNLAND, J.; HARRISON, L.; HOELL, A.; MICHAELSEN, J. The climate hazards inf rared precipitation with stations - A new environmental record for monitoring extremes. Scientific Data, v. 2, p. 1-21, 2015. https://doi.org/10.1038/sdata.2015.66

GUGLIERI, A.; ZULOAGA, F. O.; LONGHI-WAGNER, H. M. Sinopse das espécies de Panicum L. subg. Panicum (Poaceae, Paniceae) ocorrentes no Brasil 1. Acta bot. bras, v. 18, n. 2, p. 359-367, 2004. https://doi.org/10.1590/S0102-33062004000200015

HASENMUELLER, E. A.; SCOTT, K. M. Weathering of rock to regolith: The activity of deep roots in bedrock fractures. Geoderma, v. 300, p. 11-31, 2017.

https://doi.org/10.1016/j.geoderma.2017.03.020

IUSS WORKING GROUP WRB. World reference base for soil resources 2014. International soil classification system for naming soils and creating legends for soil maps. [s.l: s.n.].

KAYANO, M. T.; ANDREOLI, R. V. Clima da Região Nordeste do Brasil. In: CAVALCANTI, I. F. et al. (Eds.). . Tempo e clima no Brasil. São Paulo: Oficina de textos, 2009. p. 213-234.

LUCAS, Y. The role of plants in controlling rates and products of weathering: Importance of biological 
pumping. Annual Review of Earth and Planetary Science, v. 29, p. 135-163, 2001. https://doi.org/10.1146/annurev.earth.29.1.135

LUCENA, D. S.; SOUSA, J. M.; SILVA, R. F. L.; SOUZA, P. F. Flora vascular de um inselbergue na mesorregião do sertão paraibano, nordeste do Brasil. Scientia Plena, v. 11, n. 1, p. 1-11, 2015.

MANZONI, S.; TROFYMOW, J. A.; JACKSON, R. B.; PORPORATO, A. Stoichiometric controls on carbon, nitrogen, and phosphorus dynamics in decomposing litter. Source: Ecological Monographs Ecological Monographs, v. 80, n. 801, p. 89-106, 2010. https://doi.org/10.1890/09-0179.1

MINASNY, B.; MCBRATNEY, A. B. Limited effect of organic matter on soil available water capacity. European Journal of Soil Science, v. 69, n. 1, p. 39-47, 2018. https://doi.org/10.1111/ejss.12475

MORELLATO, L. P. C.; SILVEIRA, F. A. O. Plant life in campo rupestre: New lessons from an ancient biodiversity hotspot. Flora: Morphology, Distribution, Functional Ecology of Plants, v. 238, n. 2018, p. 1-10, 2018. https://doi.org/10.1016/j.flora.2017.12.001

NEVES, D. M.; DEXTER, K. G.; PENNINGTON, R. T.; BUENO, M. L.; MIRANDA, P. L. S.; OLIVEIRAFILHO, A. T. Lack of floristic identity in campos rupestres-A hyperdiverse mosaic of rocky montane savannas in South America. Flora: Morphology, Distribution, Functional Ecology of Plants, v. 238, p. 24-31, 2018. https://doi.org/10.1016/j.flora.2017.03.011

NOGUEIRA, R.; PEREIRA, O. L.; KASUYA, M. C. M.; LANNA, M. C. S.; LENDONÇA, M. P. Fungos micorrízicos associados a orquídeas em campos rupestres na região do Quadrilátero Ferrífero, $M G$, Brasil. Acta Botanica Brasilica, v. 19, n. 3, p. 417-424, 2005. https://doi.org/10.1590/S010233062005000300001

OLIVEIRA, R. S.; GALVÃO, H. C.; CAMPOS, M. C. R.; ELLER, C. B.; PEARSE, S. J.; LAMBERS, H. Mineral nutrition of campos rupestres plant species on contrasting nutrient-impoverished soil types.

New Phytologist, v. 205, n. 3, p. 1183-1194, 2015. https://doi.org/10.1111/nph.13175

PEREIRA, M. M. D.; BRAGA, P. E. T.; GUIOMAR, N.; SANTOS, F. D. S.; RIBEIRO, S. The flora and vegetation of rocky outcrops in three municipalities in the northern reg ion of Ceará, Brazil:

Phytosociological characterization. Rodriguesia, v. 69, n. 2, p. 281-299, 2018.

https://doi.org/10.1590/2175-7860201869202

PESSOA, E.; ALVES, M. Orchidaceae em afloramentos rochosos do estado de Pernambuco, Brasil. Rodriguesia, v. 65, n. 3, p. 717-734, 2014. https://doi.org/10.1590/2175-7860201465311

RAPINI, A.; RIBEIRO, P. L.; LAMBERT, S.; PIRANI, J. R. A flora dos campos rupestres da Cadeia do Espinhaço. Megadiversidade, v. 4, n. 1-2, p. 16-24, 2008.

RAUNKIAER, C. The liefe form of plants and statistical plants geography. Oxford: Claredon Press, 1934.

Reflora - Virtual Herbarium. Disponível em:

<http://reflora.jbrj.gov.br/reflora/herbarioVirtual/ConsultaPublicoHVUC/ConsultaPublicoHVUC.do;jses si onid=62C6E2F5897A57836BF9EB92250162CA ?http://reflora.jbrj.gov.br/reflora/herbarioVirtual/Consul taPublicoHVUC/ConsultaPublicoHVUC.do;jsessionid=62C6E2F5897A57836BF9E B92250162CA>. Acesso em: 23 jun de 2018.

RIBEIRO, K.; SOUSA-NETO; E. R.; CARVALHO JUNIOR, J. A.; LIMA, J. R. S.; MENEZES, C.; DUARTE-NETO, P. J.; GUERRA, G. S.; METTO, P. H. B. Land cover changes and greenhouse gas emissions in two different soil covers in the Brazilian Caatinga. Science of the Total Environment, v. 571, p. 1048-1057, 2016. https://doi.org/10.1016/i.scitotenv.2016.07.095

SALES-RODRIGUES, J.; BRASILEIRO, J. C.-B.; MELO, J. I. M. Flora de um inselberg na mesorregião agreste do estado da Paraíba-Brasil. Polibotánica, n. 37, p. 47-61, 2014.

SALGADO, A. A. R.; BUENO, G. T.; DINIZ, A. D.; MARENT, B. R. Long-Term Geomorphological Evolution of the Brazilian Territory. In: VIEIRA, B. C.; SALGADO, A. A. R.; SANTOS, L. J. C. (Eds.). . Landscapes and landforms of Brazil. [s.l.] Spring Netherlands, 2015. p. 19-31. https://doi.org/10.1007/978-94-017-8023-0 3

SANTANNA NETO, J. L.; GALVANI, E.; VIEIRA, B. C. Climates of Brazil: Past and Present. In: 
VIEIRA, B.; SALGADO, A.; SANTOS, L. (Eds.). . Landscapes and landforms of Brazil. [s.I.] Springer, Dordrecht, 2015. p. 33-41. https://doi.org/10.1007/978-94-017-8023-0 4

SANTOS, H. G.; CARVALHO JÚNIOR, R; DART, R. O.; AGLIO, M. L. D.; SOUZA, J. S.; PARES, J. G.; FONTANA, A.; MARTINS, A. L.; OLIVEIRA, A. P. O novo mapa de solos do Brasil: legenda atualizada. Embrapa, p. 67, 2011.

SANTOS, H. G. S.; JACOMINE, P. K. T.; ANJOS, L. H. C.; OLIVEIRA, V. A.; LUMBRERAS, J. F.; COELHO, M. R.; ALMEIDA, J. A.; ARAÚJO-FILHO, J. C. Sistema brasileiro de classificação de solos. Brasília : Embrapa, 2018.

SANTOS, J. C.; LEAL, I. R.; ALMEIDA-CORTEZ, J. S.; FERNANDES, G. W.; TABARELLI, M. Caatinga : the scientific negligence experienced by a dry tropical forest. v. 4, n. 3, p. 276-286, 2011. https://doi.org/10.1177/194008291100400306

SANTOS, M. F.; LUCAS, E.; SOBRAL, M.; SANO, P. T. New species of Myrcia s.I. (Myrtaceae) from Campo Rupestre, Atlantic Forest and Amazon Forest. Phytotaxa, v. 222, n. 2, p. 100, ago. 2015. https://doi.org/10.11646/phytotaxa.222.2.2

SARCINELLI, T. S.; SCHAEFER, C. E. G. R.; FERNANDES FILHO, E. I.; MAFIA, R. G.; NERI, A. Soil modification by termites in a sandy-soil vegetation in the Brazilian Atlantic rain forest. Journal of Tropical Ecology, v. 29, n. 5, p. 439-448, 2013. https://doi.org/10.1017/S0266467413000497

SCHAEFER, C. E. G. R.; CANDIDO, H. G.; CORREA, G.; PEREIRA, A. S.; NUNES, J.; SOUZA, O.; MARINS, A. Solos desenvolvidos sobre canga ferruginosa no Brasil. In: CARMO, F. F.; KAMINO, L. H. Y. (Eds.). . Geossitemas ferruginosos do Brasil. Belo Horizonte: 3i, 2015. p. 77-102.

SCHULZ, K.; VOIGT, K.; BEUSCH, C.; ALMEIDA-CORTEZ, J. S.; KOWARIK, I.; WALZ, A.; CIEJARCKS, A. Grazing deteriorates the soil carbon stocks of Caatinga forest ecosystems in Brazil. Forest Ecology and Management, v. 367, p. 62-70, 2016.

https://doi.org/10.1016/j.foreco.2016.02.011

SILVA, F. K. G.; Lopes, S. F.; LOPEZ, L. C. S.; MELO, J. I. M.; TROVÃO, D. M. B. M. Patterns of species richness and conservation in the Caatinga along elevational gradients in a semiarid ecosystem. Journal of Arid Environments, v. 110, 2014.

https://doi.org/10.1016/j.jaridenv.2014.05.011

SILVEIRA, F. A. O.; NEGREIROS, D.; BARBOSA, N. P. U.; BUISSON, E.; CARMO, F. F.; CARSTENSEN, D. W.; CONCEIÇÃO, A. A.; CORNELISSEN, T. G.; ECHTERNACHT, L.;

FERNANDES. G. W.; QUEILA S. GARCIA, GUERRA, T. G.; JACOBI, C. M.; LEMOS-FILHO, J. P.; LE STRADIC, S., MORELLATO, L. P. C.; NEVES, F. S.; OLIVEIRA, R. S.; SCHAEFER, C. E. G. R.; VIANA, P. L.; LAMBERS, H. Ecology and evolution of plant diversity in the endangered campo rupestre: a neglected conservation priority. Plant and Soil, v. 403, n. 1-2, p. 129-152, 2016. https://doi.org/10.1007/s11104-015-2637-8

VASCONCELOS, M. F. DE. Point of view / Coluna opinião O que são campos rupestres e campos de altitude nos topos de montanha do Leste do Brasil ? n. Silveira 1922, p. 241-246, 2011.

https://doi.org/10.1590/S0100-84042011000200012

VASILINIUC, I.; PATRICHE, C. V. Validating Soil Bulk Density Pedotransfer Functions Using a Romanian Dataset. Carpathian Journal of Earth and Environmental Sciences, v. 10, n. 2, p. 225236, 2015.

VELOSO, H. P.; RANGEL FILHO, A. L. R.; LIMA, J. C. A. Classificação da vegetação brasileira adaptada a um sistema universal. Rio de Janeiro: IBGE, 1991.

WEBERLING, F. Life in the Cerrado, a South American tropical seasonal ecosystem. Flora Morphology, Distribution, Functional Ecology of Plants, v. 203, n. 1, p. 103-104, jan. 2008. https://doi.org/10.1016/j.flora.2007.06.001

YEOMANS, J. C.; BREMNER, J. M. A rapid and precise method for routine determination of organic carbon in soil. Communications in Soil Science and Plant Analysis, v. 19, n. 13, p. 1467-1476, out. 1988. https://doi.org/10.1080/00103628809368027 


\section{SUPPLEMENTAL MATERIAL}

Table. Composition of campos rupestres in study area.

\begin{tabular}{|c|c|c|c|c|c|c|c|}
\hline \multirow[t]{2}{*}{ Family } & \multirow[t]{2}{*}{ Cientific name } & \multirow[t]{2}{*}{ Habit } & \multirow[t]{2}{*}{ Life form } & \multirow[t]{2}{*}{ Biome } & \multicolumn{3}{|c|}{ Frequency } \\
\hline & & & & & $1-5$ & $6-10$ & $\begin{array}{l}11- \\
20\end{array}$ \\
\hline Araliaceae & Aralia warmingiana & Tree & $\begin{array}{l}\text { Chamaephy } \\
\text { te }\end{array}$ & $\begin{array}{ll}\text { Caatinga, } & \text { Atlantic } \\
\text { rainforest } & \end{array}$ & $x$ & & \\
\hline $\begin{array}{c}\text { Acanthacea } \\
\mathrm{e}\end{array}$ & $\begin{array}{l}\text { Harpochilus neesianus } \\
\text { Mart. ex Nees }\end{array}$ & Herb & $\begin{array}{l}\text { Chamaephy } \\
\text { te }\end{array}$ & Caatinga & & $\mathrm{x}$ & \\
\hline $\begin{array}{c}\text { Acanthacea } \\
\mathrm{e}\end{array}$ & $\begin{array}{l}\text { Justicia aequilabris } \\
\text { (Nees) Lindau }\end{array}$ & Herb & Therophyte & $\begin{array}{l}\text { Amazon rainforest, } \\
\text { Caatinga, Cerrado }\end{array}$ & & $x$ & \\
\hline $\begin{array}{c}\text { Acanthacea } \\
\mathrm{e}\end{array}$ & Ruellia geminiflora Kunth & Herb & Therophyte & $\begin{array}{l}\text { Amazon rainforest, } \\
\text { Caatinga, Cerrado, } \\
\text { Atlantic rainforest }\end{array}$ & & $x$ & \\
\hline $\begin{array}{l}\text { Alstroemeri } \\
\text { aceae }\end{array}$ & $\begin{array}{l}\text { Bomarea edulis (Tussac) } \\
\text { Herb. }\end{array}$ & $\begin{array}{l}\text { Climbing } \\
\text { herb }\end{array}$ & Geophyte & $\begin{array}{lr}\text { Amazon } & \text { rainforest, } \\
\text { Caatinga, } & \text { Cerrado, } \\
\text { Atlantic } & \text { rainforest, } \\
\text { Pantanal } & \\
\end{array}$ & & $x$ & \\
\hline $\begin{array}{c}\text { Anacardiac } \\
\text { eae }\end{array}$ & $\begin{array}{l}\text { Schinopsis brasiliensis } \\
\text { Engl. }\end{array}$ & Tree & $\begin{array}{c}\text { Phanerophy } \\
\text { te }\end{array}$ & Caatinga, Cerrado & & $\mathrm{x}$ & \\
\hline $\begin{array}{c}\text { Anemiacea } \\
\mathrm{e} \\
\end{array}$ & Anemia sp. & Herb & $\begin{array}{l}\text { Hemicriptófi } \\
\text { to }\end{array}$ & Atlantic rainforest & & & $x$ \\
\hline $\begin{array}{c}\text { Apocynacea } \\
\mathrm{e} \\
\end{array}$ & Aspidospermasp. & Tree & $\begin{array}{l}\text { Phanerophy } \\
\text { te }\end{array}$ & Atlantic rainforest & & $x$ & \\
\hline $\begin{array}{c}\text { Apocynacea } \\
e\end{array}$ & $\begin{array}{l}\text { Mandevilla dardanoi } \\
\text { M.F.Sales et al. }\end{array}$ & Liana & Liana & Caatinga & & $x$ & \\
\hline $\begin{array}{c}\text { Apocynacea } \\
\mathrm{e} \\
\end{array}$ & $\begin{array}{l}\text { Marsdenia caatingae } \\
\text { Morillo }\end{array}$ & Liana & Liana & $\begin{array}{ll}\text { Caatinga, } & \text { Atlantic } \\
\text { rainforest }\end{array}$ & & & $\mathrm{x}$ \\
\hline Araceae & Anthurium affine Schott & Herb & $\begin{array}{l}\text { Hemicriptófi } \\
\text { to }\end{array}$ & $\begin{array}{l}\text { Caatinga, Cerrado, } \\
\text { Atlantic rainforest }\end{array}$ & & $x$ & \\
\hline Araceae & $\begin{array}{l}\text { Philodendron leal-costae } \\
\text { Mayo \& G.M.Barroso }\end{array}$ & Herb & $\begin{array}{c}\text { Chamaephy } \\
\text { te }\end{array}$ & Atlantic rainforest & & $x$ & \\
\hline Araceae & $\begin{array}{l}\text { Thaumatophyllum } \\
\text { bipinnatifidum (Schott ex } \\
\text { Endl.) Sakur., Calazans } \\
\text { \& Mayo }\end{array}$ & Herb & $\begin{array}{l}\text { Chamaephy } \\
\text { te }\end{array}$ & $\begin{array}{ll}\text { Cerrado, } & \text { Atlantic } \\
\text { rainforest } & \end{array}$ & & $\mathrm{x}$ & \\
\hline Arecaceae & $\begin{array}{l}\text { Syagrus coronata (Mart.) } \\
\text { Becc. }\end{array}$ & Tree & $\begin{array}{c}\text { Phanerophy } \\
\text { te }\end{array}$ & Caatinga, Cerrado & & $\mathrm{x}$ & \\
\hline $\begin{array}{c}\text { Aristolochia } \\
\text { ceae }\end{array}$ & $\begin{array}{l}\text { Aristolochia birostris } \\
\text { Duch. }\end{array}$ & Liana & Liana & $\begin{array}{l}\text { Caatinga, Cerrado, } \\
\text { Atlantic rainforest }\end{array}$ & & $x$ & \\
\hline Asteraceae & $\begin{array}{l}\text { Cyrtocymura scorpioides } \\
\text { (Lam.) H.Rob. }\end{array}$ & Herb & Therophyte & $\begin{array}{l}\text { Amazon rainforest, } \\
\text { Cerrado }\end{array}$ & & $x$ & \\
\hline Asteraceae & $\begin{array}{l}\text { Chresta pacourinoides } \\
\text { C.M. Siniscalchi \& B. } \\
\text { Loeuille }\end{array}$ & Herb & Therophyte & $\begin{array}{ll}\text { Caatinga, } & \text { Atlantic } \\
\text { rainforest } & \end{array}$ & & $\mathrm{x}$ & \\
\hline $\begin{array}{c}\text { Begoniacea } \\
\mathrm{e}\end{array}$ & Begonia lealii Brade & Herb & $\begin{array}{c}\text { Chamaephy } \\
\text { te } \\
\end{array}$ & Caatinga & & $\mathrm{x}$ & \\
\hline $\begin{array}{c}\text { Begoniacea } \\
\mathrm{e} \\
\end{array}$ & Begonia ulmifolia Willd. & Herb & $\begin{array}{c}\text { Chamaephy } \\
\text { te }\end{array}$ & $\begin{array}{ll}\text { Caatinga, } & \text { Atlantic } \\
\text { rainforest } & \\
\end{array}$ & & $\mathrm{x}$ & \\
\hline $\begin{array}{c}\text { Bignoniacea } \\
\mathrm{e}\end{array}$ & $\begin{array}{l}\text { Handroanthus } \\
\text { impetiginosus (Mart. ex } \\
\text { DC.) Mattos }\end{array}$ & Tree & $\begin{array}{l}\text { Phanerophy } \\
\text { te }\end{array}$ & $\begin{array}{lr}\text { Amazon } & \text { rainforest, } \\
\text { Caatinga, } & \text { Cerrado, } \\
\text { Atlantic } & \text { rainforest, } \\
\text { Pantanal } & \\
\end{array}$ & & $\bar{x}$ & \\
\hline $\begin{array}{c}\text { Boraginace } \\
\text { ae }\end{array}$ & Varronia globosa Jacq. & Shrub & $\begin{array}{c}\text { Phanerophy } \\
\text { te }\end{array}$ & $\begin{array}{ll}\begin{array}{l}\text { Caatinga, } \\
\text { rainforest }\end{array} & \text { Atlantic } \\
\end{array}$ & & $x$ & \\
\hline $\begin{array}{c}\text { Bromeliace } \\
\text { ae }\end{array}$ & Tillandsia gardneri Lindl. & Herb & $\begin{array}{l}\text { Chamaephy } \\
\text { te }\end{array}$ & $\begin{array}{lr}\text { Caatinga, } & \text { Cerrado, } \\
\text { Atlantic } & \text { rainforest, } \\
\text { Pampa } & \\
\end{array}$ & & $x$ & \\
\hline Bromeliace & Dyckia limae L.B.Sm. & Herb & Chamaephy & Caatinga & & $x$ & \\
\hline
\end{tabular}

Caminhos de Geografia Uberlândia-MG $\quad$ v. 22, n. $82 \quad$ ago./2021 $\quad$ p.115-137 Página 126 
Rubens Teixeira de Queiroz

Bartolomeu Israel de Souza José João Lelis Leal de Souza Joseilsom Ramos de Medeiros Christianne Farias da Fonseca Extending the limits of campos rupestres in Brazil Eini Celly Morais Cardoso

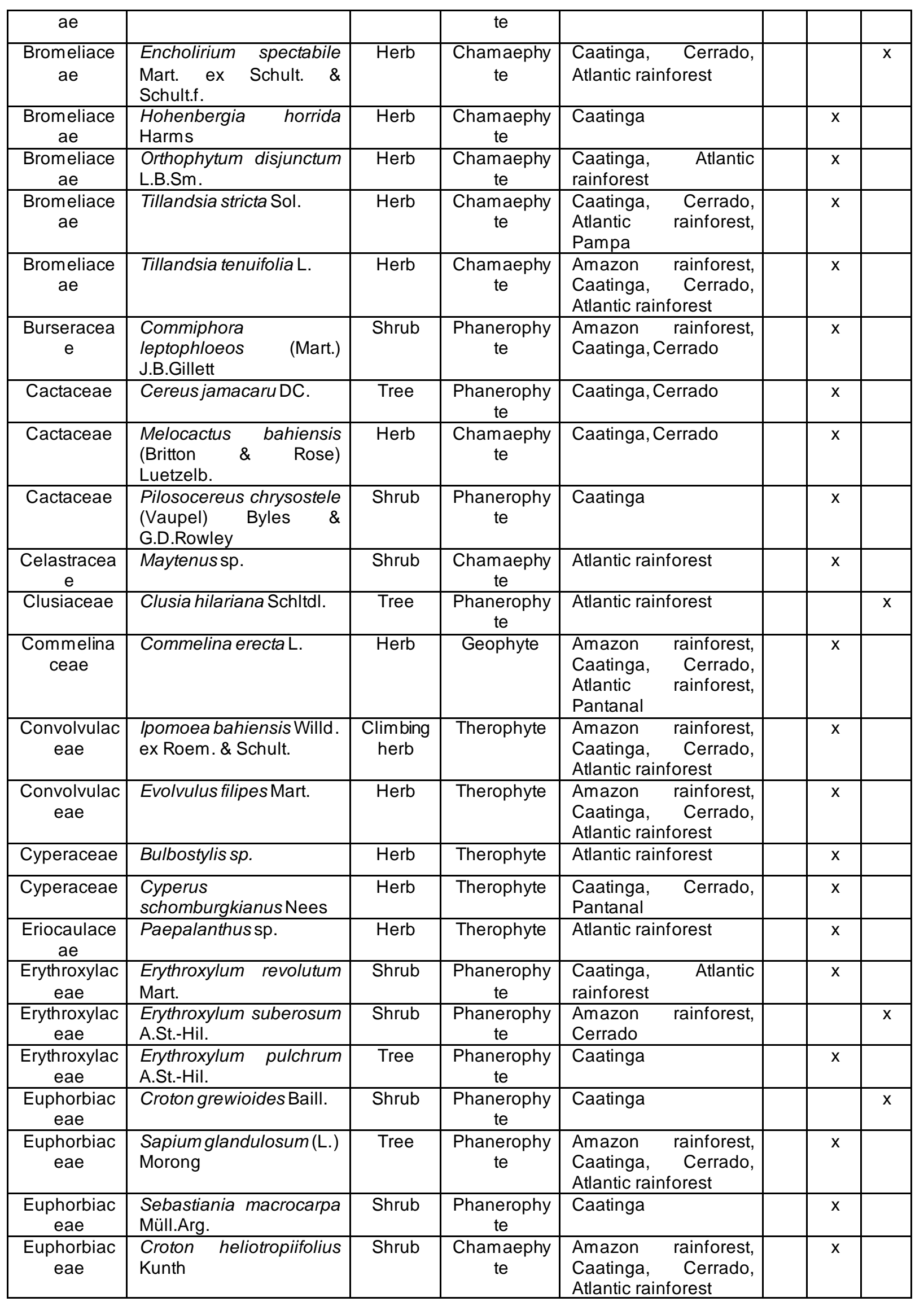


Rubens Teixeira de Queiroz

Bartolomeu Israel de Souza José João Lelis Leal de Souza Joseilsom Ramos de Medeiros Christianne Farias da Fonseca Extending the limits of campos rupestres in Brazil Eini Celly Morais Cardoso

\begin{tabular}{|c|c|c|c|c|c|c|}
\hline $\begin{array}{c}\text { Euphorbiac } \\
\text { eae }\end{array}$ & $\begin{array}{ll}\text { Cnidoscolus halteris } \\
\text { Fern.Casas }\end{array}$ & Shrub & $\begin{array}{c}\text { Chamaephy } \\
\text { te }\end{array}$ & Atlantic rainforest & $\mathrm{x}$ & \\
\hline $\begin{array}{c}\text { Euphorbiac } \\
\text { eae }\end{array}$ & $\begin{array}{l}\text { Cnidoscolus urens (L.) } \\
\text { Arthur }\end{array}$ & Shrub & $\begin{array}{l}\text { Chamaephy } \\
\text { te }\end{array}$ & $\begin{array}{lr}\text { Amazon } & \text { rainforest, } \\
\text { Caatinga, } & \text { Cerrado, } \\
\text { Atlantic } & \text { rainforest, } \\
\text { Pantanal } & \end{array}$ & $x$ & \\
\hline $\begin{array}{c}\text { Euphorbiac } \\
\text { eae }\end{array}$ & $\begin{array}{l}\text { Dalechampia } \\
\text { schenckiana Pax \& } \\
\text { K.Hoffm. }\end{array}$ & $\begin{array}{l}\text { Climbing } \\
\text { herb }\end{array}$ & Therophyte & Atlantic rainforest & $x$ & \\
\hline $\begin{array}{c}\text { Euphorbiac } \\
\text { eae }\end{array}$ & $\begin{array}{l}\text { Euphorbia heterodoxa } \\
\text { Müll.Arg. }\end{array}$ & Herb & $\begin{array}{c}\text { Chamaephy } \\
\text { te }\end{array}$ & Caatinga & $\mathrm{x}$ & \\
\hline $\begin{array}{c}\text { Euphorbiac } \\
\text { eae }\end{array}$ & $\begin{array}{l}\text { Euphorbia phosphorea } \\
\text { Mart. }\end{array}$ & Shrub & $\begin{array}{c}\text { Phanerophy } \\
\text { te }\end{array}$ & Caatinga & & $x$ \\
\hline $\begin{array}{l}\text { Euphorbiac } \\
\text { eae }\end{array}$ & Stillingia trapezoidea Ule & Shrub & $\begin{array}{c}\text { Chamaephy } \\
\text { te }\end{array}$ & Caatinga & & $x$ \\
\hline Fabaceae & $\begin{array}{l}\text { Machaerium hirtum } \\
\text { (Vell.) Stellfeld }\end{array}$ & Tree & $\begin{array}{l}\text { Phanerophy } \\
\text { te }\end{array}$ & $\begin{array}{lr}\text { Amazon } & \text { rainforest, } \\
\text { Caatinga, } & \text { Cerrado, } \\
\text { Atlantic } & \text { rainforest, } \\
\text { Pantanal } & \\
\end{array}$ & $x$ & \\
\hline Fabaceae & $\begin{array}{l}\text { Mimosa tenuiflora (Willd.) } \\
\text { Poir. }\end{array}$ & Shrub & $\begin{array}{c}\text { Phanerophy } \\
\text { te }\end{array}$ & Caatinga, Cerrado & $\mathrm{x}$ & \\
\hline Fabaceae & Erythrina velutina Willd. & Tree & $\begin{array}{c}\text { Phanerophy } \\
\text { te }\end{array}$ & Caatinga, Cerrado & $x$ & \\
\hline Fabaceae & $\begin{array}{l}\text { Albizia polycephala } \\
\text { (Benth.) Killip ex Record }\end{array}$ & Tree & $\begin{array}{c}\text { Phanerophy } \\
\text { te }\end{array}$ & $\begin{array}{l}\text { Caatinga, Cerrado, } \\
\text { Atlantic rainforest }\end{array}$ & $x$ & \\
\hline Fabaceae & $\begin{array}{l}\text { Anadenanthera colubrina } \\
\text { (Vell.) Brenan }\end{array}$ & Shrub & $\begin{array}{c}\text { Phanerophy } \\
\text { te }\end{array}$ & $\begin{array}{l}\text { Caatinga, Cerrado, } \\
\text { Atlantic rainforest }\end{array}$ & $\mathrm{x}$ & \\
\hline Fabaceae & $\begin{array}{l}\text { Bauhinia subclavata } \\
\text { Benth. }\end{array}$ & Shrub & $\begin{array}{c}\text { Phanerophy } \\
\text { te }\end{array}$ & Caatinga, Cerrado & $\mathrm{x}$ & \\
\hline Fabaceae & $\begin{array}{l}\text { Bowdichia virgilioides } \\
\text { Kunth }\end{array}$ & Tree & $\begin{array}{l}\text { Phanerophy } \\
\text { te }\end{array}$ & $\begin{array}{lr}\text { Amazon } & \text { rainforest, } \\
\text { Caatinga, } & \text { Cerrado, } \\
\text { Atlantic } & \text { rainforest, } \\
\text { Pantanal } & \end{array}$ & $x$ & \\
\hline Fabaceae & $\begin{array}{l}\text { Canavalia brasiliensis } \\
\text { Mart. ex Benth. }\end{array}$ & Liana & Liana & $\begin{array}{l}\text { Amazon rainforest, } \\
\text { Caatinga, Cerrado, } \\
\text { Atlantic rainforest }\end{array}$ & $x$ & \\
\hline Fabaceae & $\begin{array}{l}\text { Centrosema arenarium } \\
\text { Benth. }\end{array}$ & $\begin{array}{l}\text { Climbing } \\
\text { herb }\end{array}$ & Therophyte & $\begin{array}{l}\text { Caatinga, Cerrado, } \\
\text { Atlantic rainforest }\end{array}$ & & $x$ \\
\hline Fabaceae & $\begin{array}{l}\text { Chamaecrista amiciella } \\
\text { (H.S.Irwin \& Barneby) } \\
\text { H.S.Irwin \& Barneby }\end{array}$ & Herb & Therophyte & Caatinga & $x$ & \\
\hline Fabaceae & $\begin{array}{l}\text { Chamaecrista calycioides } \\
\text { (DC. ex Collad.) Greene }\end{array}$ & Herb & Therophyte & $\begin{array}{l}\text { Amazon rainforest, } \\
\text { Caatinga, Cerrado, } \\
\text { Atlantic rainforest }\end{array}$ & $x$ & \\
\hline Fabaceae & $\begin{array}{l}\text { Chamaecrista } \\
\text { zygophylloides (Taub.) } \\
\text { H.S.Irwin \& Barneby }\end{array}$ & Shrub & $\begin{array}{l}\text { Phanerophy } \\
\text { te }\end{array}$ & $\begin{array}{l}\text { Caatinga, Cerrado, } \\
\text { Atlantic rainforest }\end{array}$ & $\mathrm{x}$ & \\
\hline Fabaceae & $\begin{array}{l}\text { Chloroleucon foliolosum } \\
\text { (Benth.) G.P.Lewis }\end{array}$ & Tree & $\begin{array}{l}\text { Phanerophy } \\
\text { te }\end{array}$ & $\begin{array}{lr}\text { Amazon rainforest, } \\
\text { Caatinga, Cerrado, } \\
\text { Atlantic rainforest } \\
\end{array}$ & $\mathrm{x}$ & \\
\hline Fabaceae & $\begin{array}{l}\text { Crotalaria vitellina Ker } \\
\text { Gawl. }\end{array}$ & Herb & Therophyte & $\begin{array}{l}\text { Caatinga, Cerrado, } \\
\text { Atlantic rainforest }\end{array}$ & $x$ & \\
\hline Fabaceae & Dalbergia catingicola & Tree & $\begin{array}{c}\text { Phanerophy } \\
\text { te }\end{array}$ & Atlantic rainforest & $x$ & \\
\hline Fabaceae & $\begin{array}{l}\text { Dioclea lasiophylla Mart. } \\
\text { ex Benth. }\end{array}$ & Liana & Liana & $\begin{array}{ll}\text { Caatinga, } & \text { Atlantic } \\
\text { rainforest } & \\
\end{array}$ & $\mathrm{x}$ & \\
\hline Fabaceae & Enterolobiumsp. & Tree & $\begin{array}{c}\text { Phanerophy } \\
\text { te }\end{array}$ & Atlantic rainforest & $\mathrm{x}$ & \\
\hline Fabaceae & $\begin{array}{l}\text { Libidibia ferrea (Mart. ex } \\
\text { Tul.) L.P.Queiroz }\end{array}$ & Tree & $\begin{array}{c}\text { Phanerophy } \\
\text { te }\end{array}$ & $\begin{array}{l}\text { Caatinga, Cerrado, } \\
\text { Atlantic rainforest }\end{array}$ & $x$ & \\
\hline Fabaceae & Mimosa arenosa (Willd.) & Shrub & Phanerophy & Caatinga, Cerrado, & $x$ & \\
\hline
\end{tabular}

Caminhos de Geografia $\quad$ Uberlândia-MG $\quad$ v. 22, n. $82 \quad$ ago./2021 $\quad$ p.115-137 Página 128 
Rubens Teixeira de Queiroz

Bartolomeu Israel de Souza José João Lelis Leal de Souza Joseilsom Ramos de Medeiros Christianne Farias da Fonseca

Extending the limits of campos rupestres in Brazil Eini Celly Morais Cardoso

\begin{tabular}{|c|c|c|c|c|c|c|}
\hline & Poir. & & te & Atlantic rainforest & & \\
\hline Fabaceae & $\begin{array}{l}\text { Mimosa borboremae } \\
\text { Harms }\end{array}$ & Shrub & $\begin{array}{l}\text { Hemicriptófi } \\
\text { to }\end{array}$ & Caatinga & $x$ & \\
\hline Fabaceae & Mimosa sensitiva L. & $\begin{array}{l}\text { Climbing } \\
\text { herb }\end{array}$ & Therophyte & $\begin{array}{l}\text { Amazon rainforest, } \\
\text { Caatinga, Cerrado, } \\
\text { Atlantic rainforest }\end{array}$ & $x$ & \\
\hline Fabaceae & $\begin{array}{l}\text { Muellera campestris } \\
\text { (Mart. ex Benth.) M.J. } \\
\text { Silva \& A.M.G. Azevedo }\end{array}$ & Tree & $\begin{array}{l}\text { Phanerophy } \\
\text { te }\end{array}$ & Atlantic rainforest & $x$ & \\
\hline Fabaceae & $\begin{array}{l}\text { Piptadenia stipulacea } \\
\text { (Benth.) Ducke }\end{array}$ & Shrub & $\begin{array}{c}\text { Phanerophy } \\
\text { te }\end{array}$ & Caatinga & $x$ & \\
\hline Fabaceae & $\begin{array}{l}\text { Platymiscium floribundum } \\
\text { Vogel }\end{array}$ & Tree & $\begin{array}{c}\text { Phanerophy } \\
\text { te }\end{array}$ & $\begin{array}{l}\text { Caatinga, Cerrado, } \\
\text { Atlantic rainforest }\end{array}$ & $x$ & \\
\hline Fabaceae & $\begin{array}{l}\text { Poecilanthe grandiflora } \\
\text { Benth }\end{array}$ & Tree & $\begin{array}{c}\text { Phanerophy } \\
\text { te }\end{array}$ & Caatinga & $x$ & \\
\hline Fabaceae & $\begin{array}{l}\text { Senegalia polyphylla } \\
\text { (DC.) Britton \& Rose }\end{array}$ & Tree & $\begin{array}{l}\text { Phanerophy } \\
\text { te }\end{array}$ & $\begin{array}{lr}\text { Amazon } & \text { rainforest, } \\
\text { Caatinga, } & \text { Cerrado, } \\
\text { Atlantic } & \text { rainforest, } \\
\text { Pantanal } & \\
\end{array}$ & $x$ & \\
\hline Fabaceae & $\begin{array}{l}\text { Senna martiana (Benth.) } \\
\text { H.S.Irwin \& Barneby }\end{array}$ & Shrub & $\begin{array}{c}\text { Phanerophy } \\
\text { te }\end{array}$ & Caatinga & $x$ & \\
\hline Fabaceae & $\begin{array}{l}\text { Senna rizzinii H.S.Irwin \& } \\
\text { Barneby }\end{array}$ & Shrub & $\begin{array}{c}\text { Chamaephy } \\
\text { te }\end{array}$ & Caatinga, Cerrado & $x$ & \\
\hline Fabaceae & $\begin{array}{l}\text { Senna angulata (Vogel) } \\
\text { H.S. Irwin \& Barneby }\end{array}$ & Shrub & $\begin{array}{c}\text { Phanerophy } \\
\text { te }\end{array}$ & Atlantic rainforest & & $\bar{x}$ \\
\hline Fabaceae & $\begin{array}{l}\text { Senna spectabilis (DC.) } \\
\text { H.S.Irwin \& Barneby }\end{array}$ & Shrub & $\begin{array}{l}\text { Phanerophy } \\
\text { te }\end{array}$ & $\begin{array}{l}\text { Amazon rainforest, } \\
\text { Caatinga, Cerrado, } \\
\text { Atlantic rainforest }\end{array}$ & $\mathrm{x}$ & \\
\hline Fabaceae & $\begin{array}{l}\text { Stylosanthes viscosa (L.) } \\
\text { Sw. }\end{array}$ & Herb & $\begin{array}{l}\text { Chamaephy } \\
\text { te }\end{array}$ & $\begin{array}{l}\text { Amazon rainforest, } \\
\text { Caatinga, Cerrado, } \\
\text { Atlantic rainforest }\end{array}$ & $x$ & \\
\hline Lamiaceae & $\begin{array}{l}\text { Leptohyptis } \\
\text { macrostachys (Benth.) } \\
\text { Harley \& J.F.B.Pastore }\end{array}$ & Herb & Therophyte & Caatinga, Cerrado & $x$ & \\
\hline $\begin{array}{l}\text { Linderniace } \\
\text { ae }\end{array}$ & $\begin{array}{l}\text { Ameroglossum } \\
\text { pernambucense Eb. } \\
\text { Fisch. et al. }\end{array}$ & Shrub & Therophyte & Caatinga & $x$ & \\
\hline Loasaceae & $\begin{array}{l}\text { Aosa rupestris (Gardner) } \\
\text { Weigend }\end{array}$ & Herb & Therophyte & $\begin{array}{ll}\text { Caatinga, } & \text { Atlantic } \\
\text { rainforest }\end{array}$ & $x$ & \\
\hline $\begin{array}{l}\text { Malpighiace } \\
\text { ae }\end{array}$ & $\begin{array}{l}\text { Byrsonima stipulacea } \\
\text { A.Juss. }\end{array}$ & Tree & $\begin{array}{c}\text { Phanerophy } \\
\text { te }\end{array}$ & $\begin{array}{l}\text { Amazon rainforest, } \\
\text { Atlantic rainforest }\end{array}$ & $x$ & \\
\hline $\begin{array}{c}\text { Marantacea } \\
\mathrm{e}\end{array}$ & Maranta protracta Miq. & Herb & Geophyte & $\begin{array}{l}\text { Amazon rainforest, } \\
\text { Atlantic rainforest }\end{array}$ & $x$ & \\
\hline $\begin{array}{l}\text { Melastomat } \\
\text { aceae }\end{array}$ & $\begin{array}{l}\text { Tibouchina gardneriana } \\
\text { (Triana) Cogn. }\end{array}$ & Shrub & $\begin{array}{c}\text { Chamaephy } \\
\text { te }\end{array}$ & Atlantic rainforest & $x$ & \\
\hline Myrtaceae & $\begin{array}{l}\text { Campomanesia } \\
\text { eugenioides (Cambess.) } \\
\text { D.Legrand ex Landrum }\end{array}$ & Tree & $\begin{array}{l}\text { Phanerophy } \\
\text { te }\end{array}$ & $\begin{array}{l}\text { Caatinga, Cerrado, } \\
\text { Atlantic rainforest }\end{array}$ & $x$ & \\
\hline Myrtaceae & Eugeniasp. & Shrub & $\begin{array}{c}\text { Phanerophy } \\
\text { te }\end{array}$ & Atlantic rainforest & $\mathrm{x}$ & \\
\hline Myrtaceae & $\begin{array}{l}\text { Myrcia tomentosa (Aubl.) } \\
\text { DC. }\end{array}$ & Shrub & $\begin{array}{l}\text { Phanerophy } \\
\text { te }\end{array}$ & $\begin{array}{l}\text { Amazon rainforest, } \\
\text { Caatinga, Cerrado, } \\
\text { Atlantic rainforest }\end{array}$ & & $\mathrm{x}$ \\
\hline $\begin{array}{c}\text { Nyctaginace } \\
\text { ae }\end{array}$ & $\begin{array}{lll}\text { Guapira } & \text { laxa } & \text { (Netto) } \\
\text { Furlan } & & \\
\end{array}$ & Tree & $\begin{array}{l}\text { Phanerophy } \\
\text { te }\end{array}$ & Caatinga & $x$ & \\
\hline Oleaceae & Ximenia americana L. & Shrub & $\begin{array}{l}\text { Phanerophy } \\
\text { te }\end{array}$ & $\begin{array}{l}\text { Amazon rainforest, } \\
\text { Caatinga, Cerrado, } \\
\text { Atlantic rainforest }\end{array}$ & $x$ & \\
\hline $\begin{array}{c}\text { Orchidacea } \\
\mathrm{e}\end{array}$ & Alatiglossum barbatum & Herb & $\begin{array}{c}\text { Chamaephy } \\
\text { te }\end{array}$ & Atlantic rainforest & $x$ & \\
\hline
\end{tabular}


Rubens Teixeira de Queiroz

Bartolomeu Israel de Souza José João Lelis Leal de Souza Joseilsom Ramos de Medeiros Christianne Farias da Fonseca Extending the limits of campos rupestres in Brazil Eini Celly Morais Cardoso

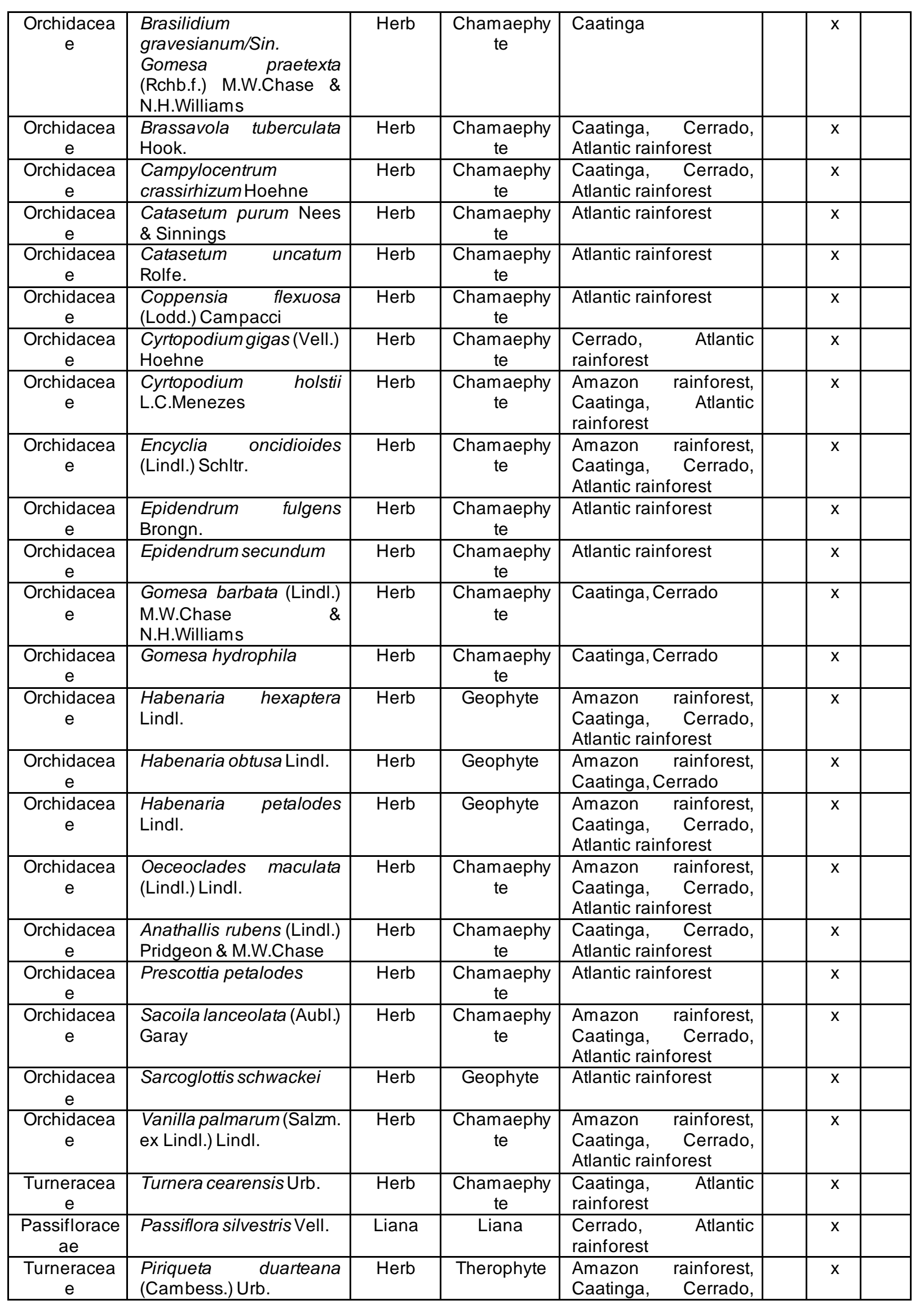


Rubens Teixeira de Queiroz

Bartolomeu Israel de Souza José João Lelis Leal de Souza Joseilsom Ramos de Medeiros Christianne Farias da Fonseca

Extending the limits of campos rupestres in Brazil Eini Celly Morais Cardoso

\begin{tabular}{|c|c|c|c|c|c|c|c|}
\hline & & & & Atlantic rainforest & & & \\
\hline $\begin{array}{c}\text { Phyllanthac } \\
\text { eae }\end{array}$ & $\begin{array}{l}\text { Phyllanthus claussenii } \\
\text { Müll.Arg. }\end{array}$ & Shrub & $\begin{array}{c}\text { Chamaephy } \\
\text { te }\end{array}$ & Atlantic rainforest & & & $x$ \\
\hline Piperaceae & Piperomiasp. & Herb & Therophyte & Atlantic rainforest & & $x$ & \\
\hline Poaceae & Melinis glutinosa & Herb & Therophyte & Cerrado & & $\mathrm{x}$ & \\
\hline $\begin{array}{c}\text { Polygalacea } \\
\text { e }\end{array}$ & $\begin{array}{ll}\text { Acanthocladus } & \\
\text { dichromus } & \text { (Steud.) } \\
\text { J.F.B.Pastore } & \\
\end{array}$ & Shrub & $\begin{array}{l}\text { Phanerophy } \\
\text { te }\end{array}$ & Caatinga & $\mathrm{x}$ & & \\
\hline $\begin{array}{c}\text { Polygalacea } \\
\text { e }\end{array}$ & Polygala paniculata L. & Herb & Therophyte & $\begin{array}{lr}\text { Amazon } & \text { rainforest, } \\
\text { Caatinga, } & \text { Cerrado, } \\
\text { Atlantic } & \text { rainforest, } \\
\text { Pampa } & \\
\end{array}$ & & $x$ & \\
\hline $\begin{array}{c}\text { Polygalacea } \\
\text { e }\end{array}$ & $\begin{array}{l}\text { Securidaca diversifolia } \\
\text { (L.) S.F.Blake }\end{array}$ & Liana & Liana & $\begin{array}{l}\text { Amazon rainforest, } \\
\text { Caatinga, Cerrado, } \\
\text { Atlantic rainforest }\end{array}$ & & $x$ & \\
\hline $\begin{array}{c}\text { Polygonace } \\
\text { ae }\end{array}$ & $\begin{array}{ll}\text { Ruprechtia laxiflora } \\
\text { Meisn. }\end{array}$ & Tree & $\begin{array}{c}\text { Phanerophy } \\
\text { te }\end{array}$ & $\begin{array}{ll}\text { Caatinga, } & \text { Atlantic } \\
\text { rainforest } & \end{array}$ & & $\mathrm{x}$ & \\
\hline $\begin{array}{l}\text { Polypodiace } \\
\text { ae }\end{array}$ & $\begin{array}{l}\text { Microgramma } \\
\text { vacciniifolia (Langsd. \& } \\
\text { Fisch.) Copel. }\end{array}$ & Herb & $\begin{array}{c}\text { Chamaephy } \\
\text { te }\end{array}$ & Atlantic rainforest & & $x$ & \\
\hline Rubiaceae & Randia armata (Sw.) DC. & Shrub & $\begin{array}{l}\text { Phanerophy } \\
\text { te }\end{array}$ & $\begin{array}{l}\text { Amazon rainforest, } \\
\text { Caatinga, Cerrado, } \\
\text { Atlantic rainforest }\end{array}$ & & $x$ & \\
\hline Rubiaceae & $\begin{array}{lr}\text { Tocoyena } & \text { sellowiana } \\
\text { (Cham. \& } & \text { Schltdl.) } \\
\text { K.Schum. } & \\
\end{array}$ & Shrub & $\begin{array}{l}\text { Phanerophy } \\
\text { te }\end{array}$ & $\begin{array}{lr}\text { Amazon } & \text { rainforest, } \\
\text { Caatinga, } & \text { Atlantic } \\
\text { rainforest } & \\
\end{array}$ & & $x$ & \\
\hline Rubiaceae & $\begin{array}{l}\text { Chiococca alba } \\
\text { Hitchc. }\end{array}$ & Shrub & $\begin{array}{c}\text { Phanerophy } \\
\text { te }\end{array}$ & $\begin{array}{lr}\text { Amazon } & \text { rainforest, } \\
\text { Caatinga, } & \text { Cerrado, } \\
\text { Atlantic } & \text { rainforest, } \\
\text { Pantanal } & \end{array}$ & & $x$ & \\
\hline Rubiaceae & Staeliasp. & Herb & Therophyte & Atlantic rainforest & & $x$ & \\
\hline Rutaceae & $\begin{array}{l}\text { Zanthoxylum rhoifolium } \\
\text { Lam. }\end{array}$ & Tree & $\begin{array}{l}\text { Phanerophy } \\
\text { te }\end{array}$ & $\begin{array}{l}\text { Amazon rainforest, } \\
\text { Caatinga, } \quad \text { Cerrado, } \\
\text { Atlantic rainforest, } \\
\text { Pampa, Pantanal }\end{array}$ & & $x$ & \\
\hline Salicaceae & $\begin{array}{l}\text { Prockia crucis P.Browne } \\
\text { ex L. }\end{array}$ & Shrub & $\begin{array}{c}\text { Phanerophy } \\
\text { te }\end{array}$ & $\begin{array}{l}\text { Amazon rainforest, } \\
\text { Caatinga, Cerrado, } \\
\text { Atlantic rainforest }\end{array}$ & & $x$ & \\
\hline $\begin{array}{c}\text { Sapindacea } \\
\mathrm{e}\end{array}$ & $\begin{array}{l}\text { Allophylus quercifolius } \\
\text { (Mart.) Radlk. }\end{array}$ & Tree & $\begin{array}{c}\text { Phanerophy } \\
\text { te }\end{array}$ & Caatinga, Cerrado & & $x$ & \\
\hline Sapotaceae & $\begin{array}{l}\text { Manilkara rufula (Miq.) } \\
\text { H.J.Lam }\end{array}$ & Tree & $\begin{array}{c}\text { Phanerophy } \\
\text { te }\end{array}$ & Caatinga, Cerrado & & $x$ & \\
\hline $\begin{array}{c}\text { Schoepfiace } \\
\text { ae }\end{array}$ & $\begin{array}{l}\text { Schoepfia brasiliensis } \\
\text { A.DC. }\end{array}$ & Tree & $\begin{array}{l}\text { Phanerophy } \\
\text { te }\end{array}$ & $\begin{array}{l}\text { Amazon rainforest, } \\
\text { Caatinga, Cerrado, } \\
\text { Atlantic rainforest }\end{array}$ & & $x$ & \\
\hline Solanaceae & $\begin{array}{l}\text { Solanum jabrense Agra \& } \\
\text { M.Nee }\end{array}$ & Shrub & $\begin{array}{c}\text { Chamaephy } \\
\text { te }\end{array}$ & $\begin{array}{ll}\text { Caatinga, } & \text { Atlantic } \\
\text { rainforest }\end{array}$ & $\mathrm{x}$ & & \\
\hline Solanaceae & $\begin{array}{l}\text { Solanum rhytidoandrum } \\
\text { Sendtn. }\end{array}$ & Shrub & $\begin{array}{c}\text { Chamaephy } \\
\text { te }\end{array}$ & $\begin{array}{l}\text { Amazon rainforest, } \\
\text { Caatinga, Cerrado }\end{array}$ & & $x$ & \\
\hline Solanaceae & $\begin{array}{l}\text { Solanum stipulaceum } \\
\text { Willd. ex Roem. \& Schult. }\end{array}$ & Shrub & $\begin{array}{c}\text { Chamaephy } \\
\text { te }\end{array}$ & $\begin{array}{l}\text { Caatinga, Cerrado, } \\
\text { Atlantic rainforest }\end{array}$ & & $x$ & \\
\hline Vitaceae & $\begin{array}{l}\text { Clematicissus } \\
\text { simsimiana }\end{array}$ & Liana & Liana & Caatinga & & $x$ & \\
\hline Vitaceae & $\begin{array}{l}\text { Cissus blanchetiana } \\
\text { Planch. }\end{array}$ & Liana & Liana & $\begin{array}{l}\text { Caatinga, } \\
\text { rainforest }\end{array}$ & & $x$ & \\
\hline Vitaceae & Cissus subrhomboidea & Liana & Liana & $\begin{array}{l}\text { Caatinga, } \\
\text { rainforest }\end{array}$ & & $x$ & \\
\hline
\end{tabular}


Rubens Teixeira de Queiroz

Bartolomeu Israel de Souza José João Lelis Leal de Souza Joseilsom Ramos de Medeiros Christianne Farias da Fonseca
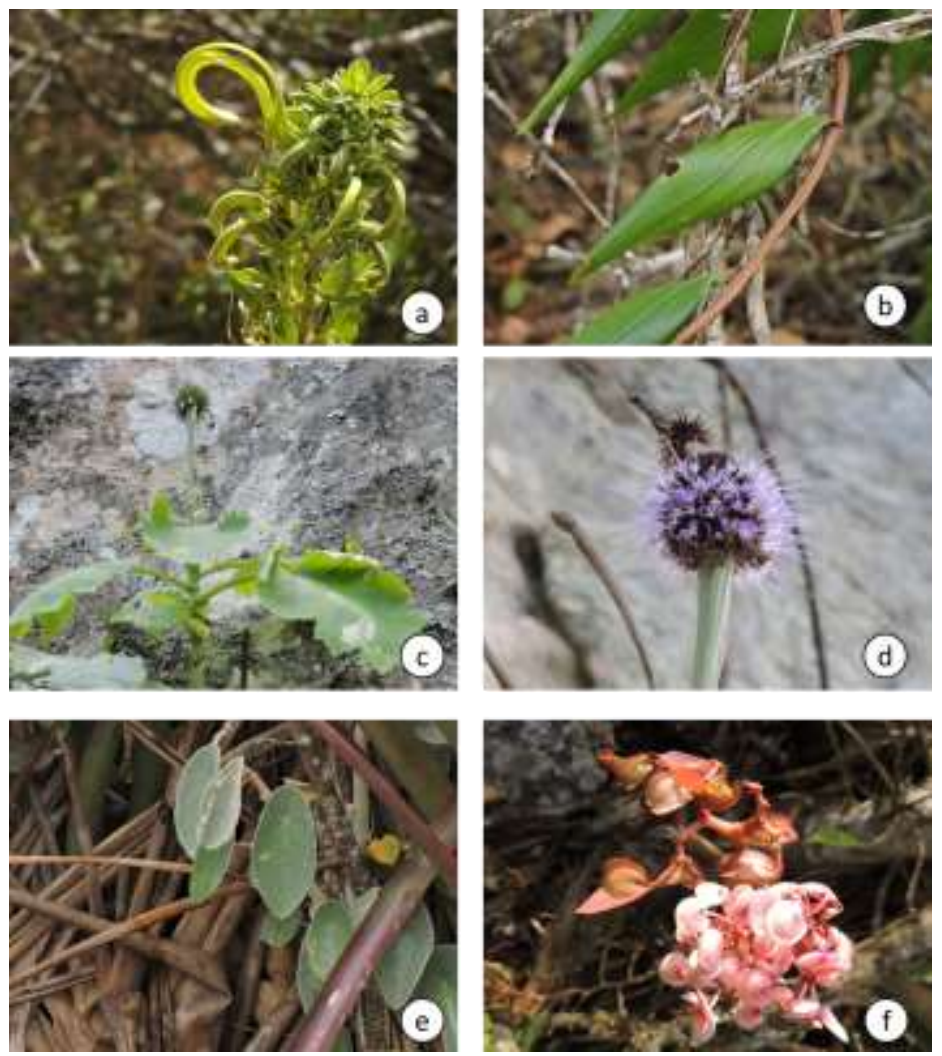

Figure I - a - Harpochilus neesianus Mart. ex Nees; b - Bomarea edulis (Tussac) Herb.; c-d - Chresta pacourinoides C.M. Siniscalchi \& B. Loeuille; e-f - Begonia lealii Brade
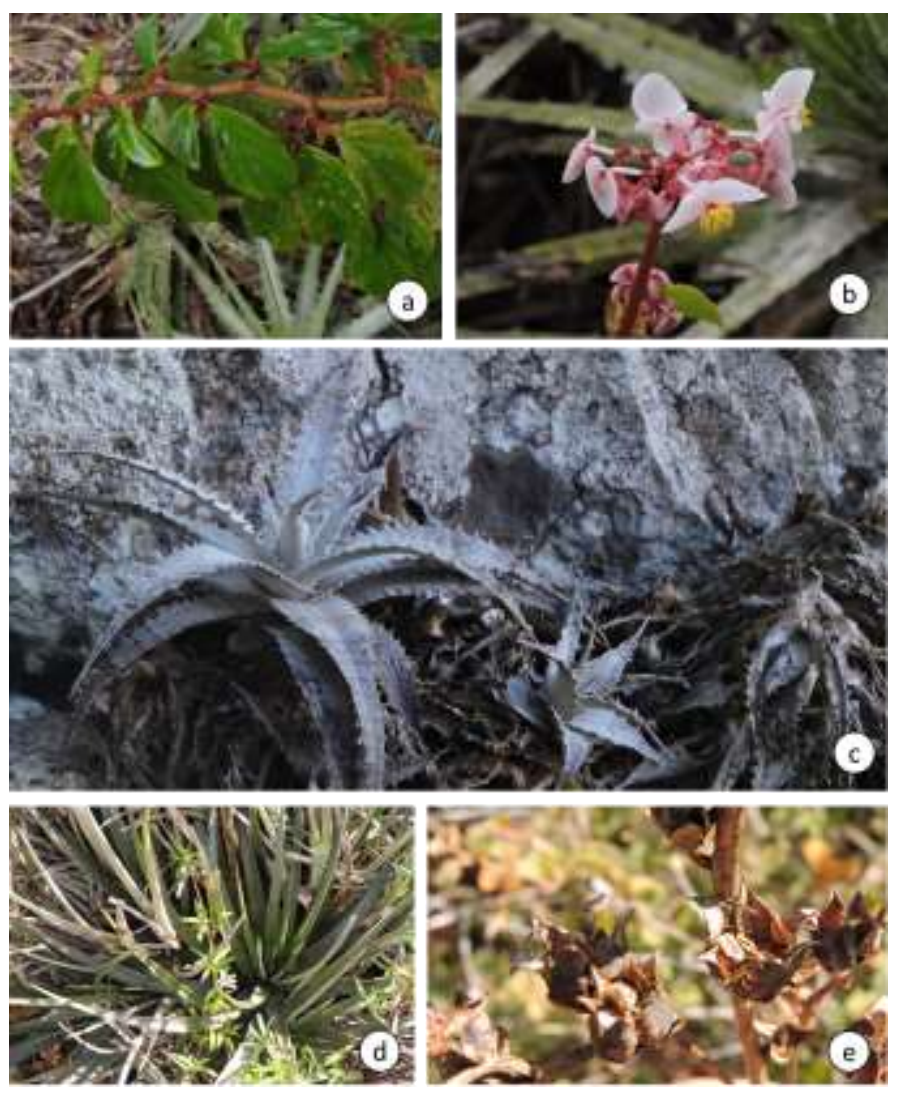
Rubens Teixeira de Queiroz

Bartolomeu Israel de Souza José João Lelis Leal de Souza Joseilsom Ramos de Medeiros Christianne Farias da Fonseca
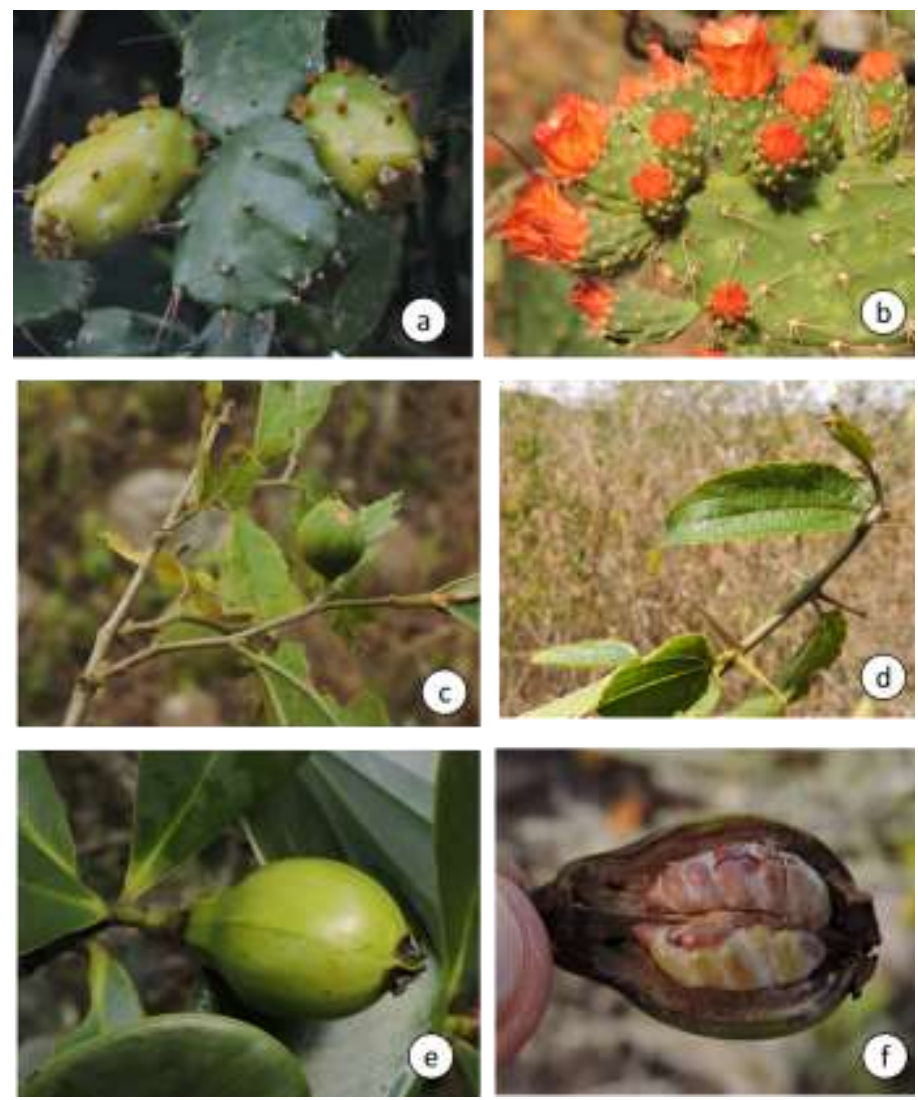

Figure III - a - Brasiliopuntia brasiliensis (Willd.) A.Berger; b - Tacinga palmadora (Britton \& Rose) N.P.Taylor \& Stuppy; c-d - Celtis alnifolia (Wedd.) Miq.; e-f - Clusia hilariana Schltdl.
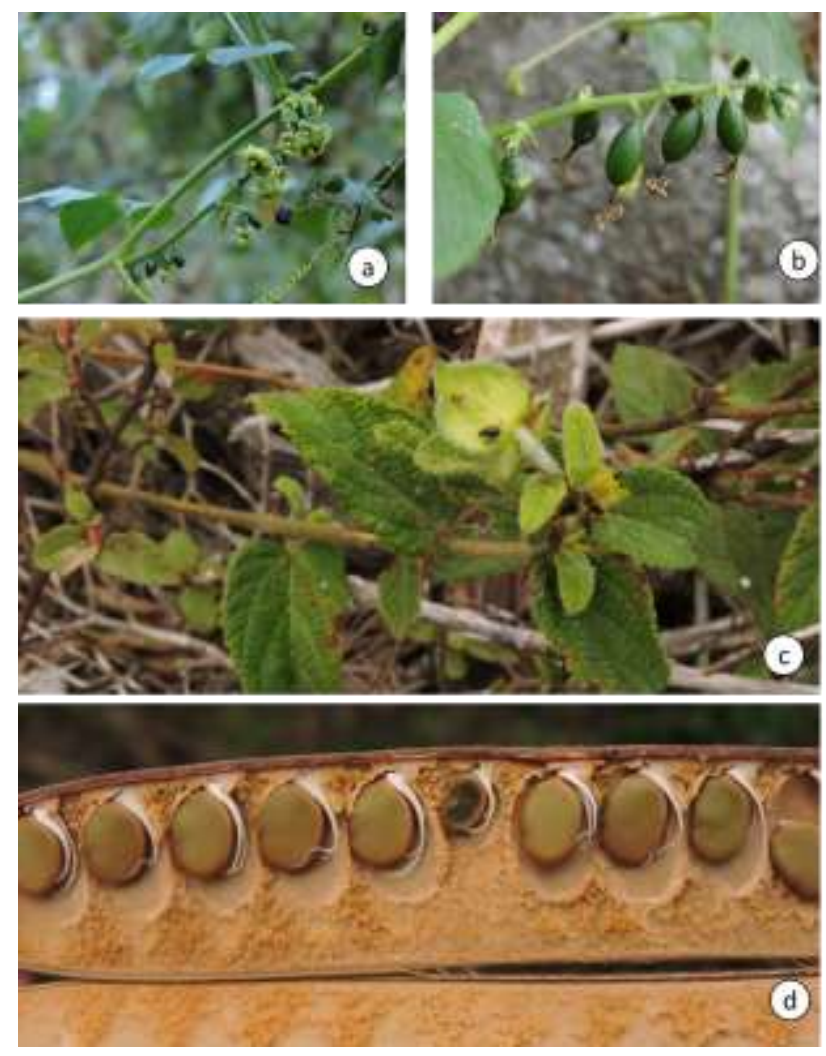
Rubens Teixeira de Queiroz

Bartolomeu Israel de Souza José João Lelis Leal de Souza Joseilsom Ramos de Medeiros
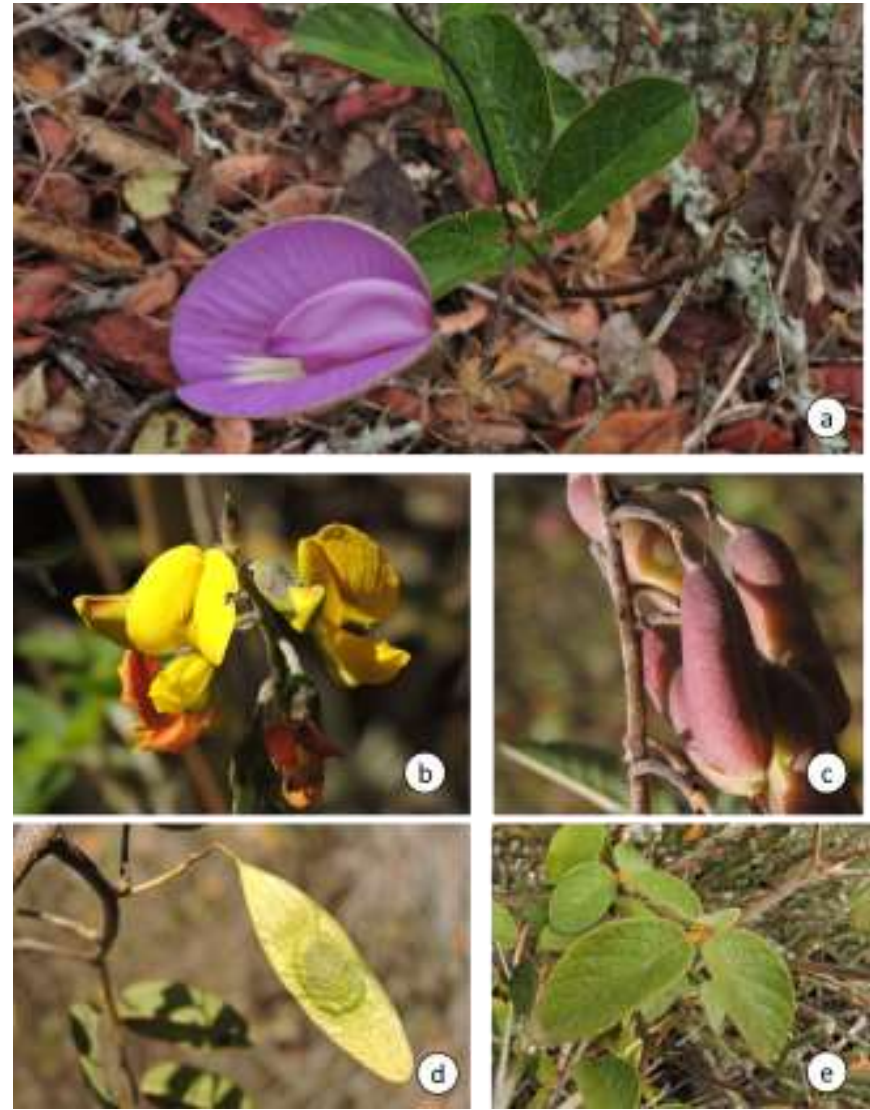

Figure V - a - Centrosema arenarium Benth.; b-c - Crotalaria vitellina Ker Gawl; d - Dalbergia sp.; e - Dioclea lasiophylla Mart. ex Benth.
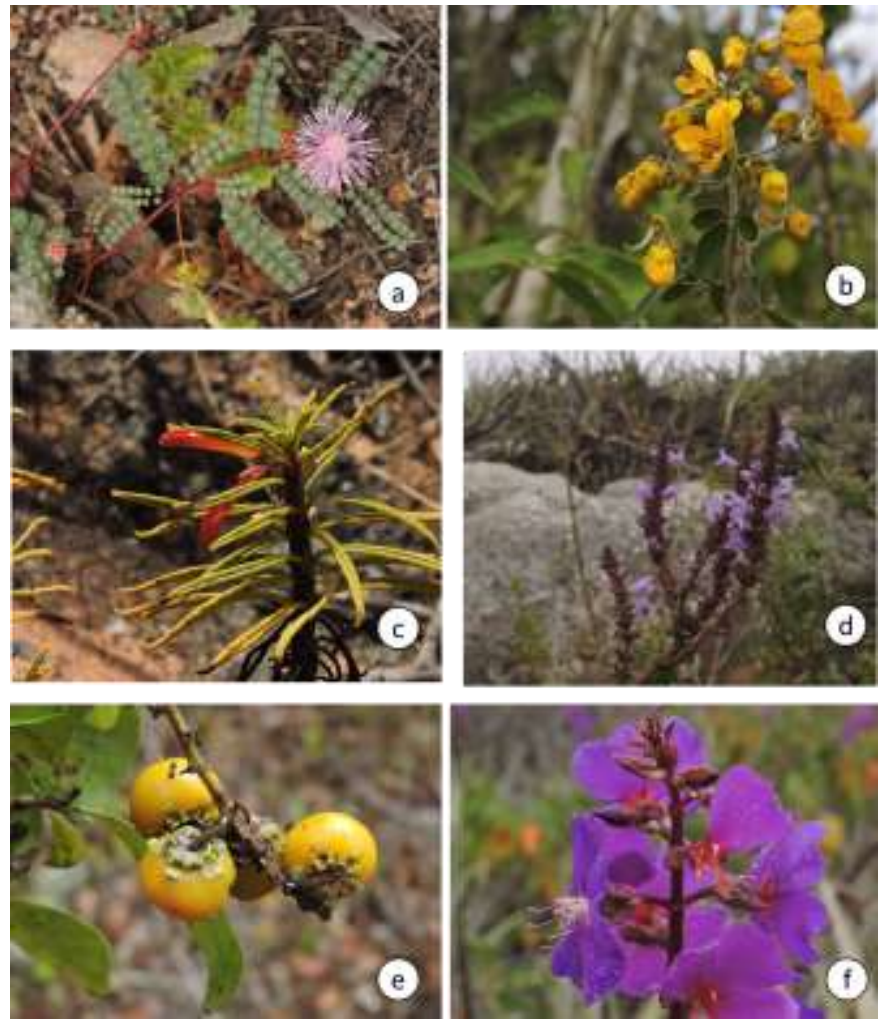
Rubens Teixeira de Queiroz

Bartolomeu Israel de Souza José João Lelis Leal de Souza Joseilsom Ramos de Medeiros Christianne Farias da Fonseca

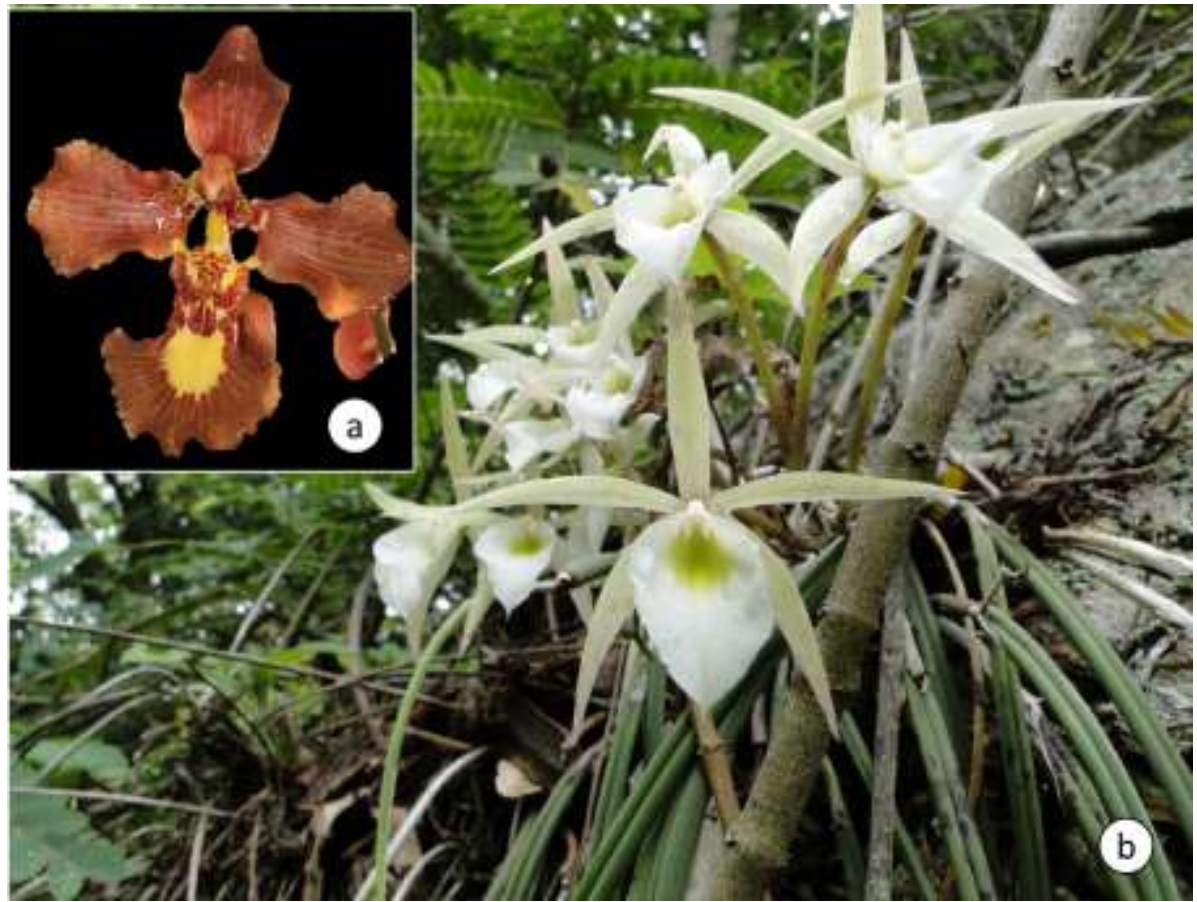

Figure VII - a - Brasilidium gravesianum; b-Brassavola tuberculata Hook.. fotos:
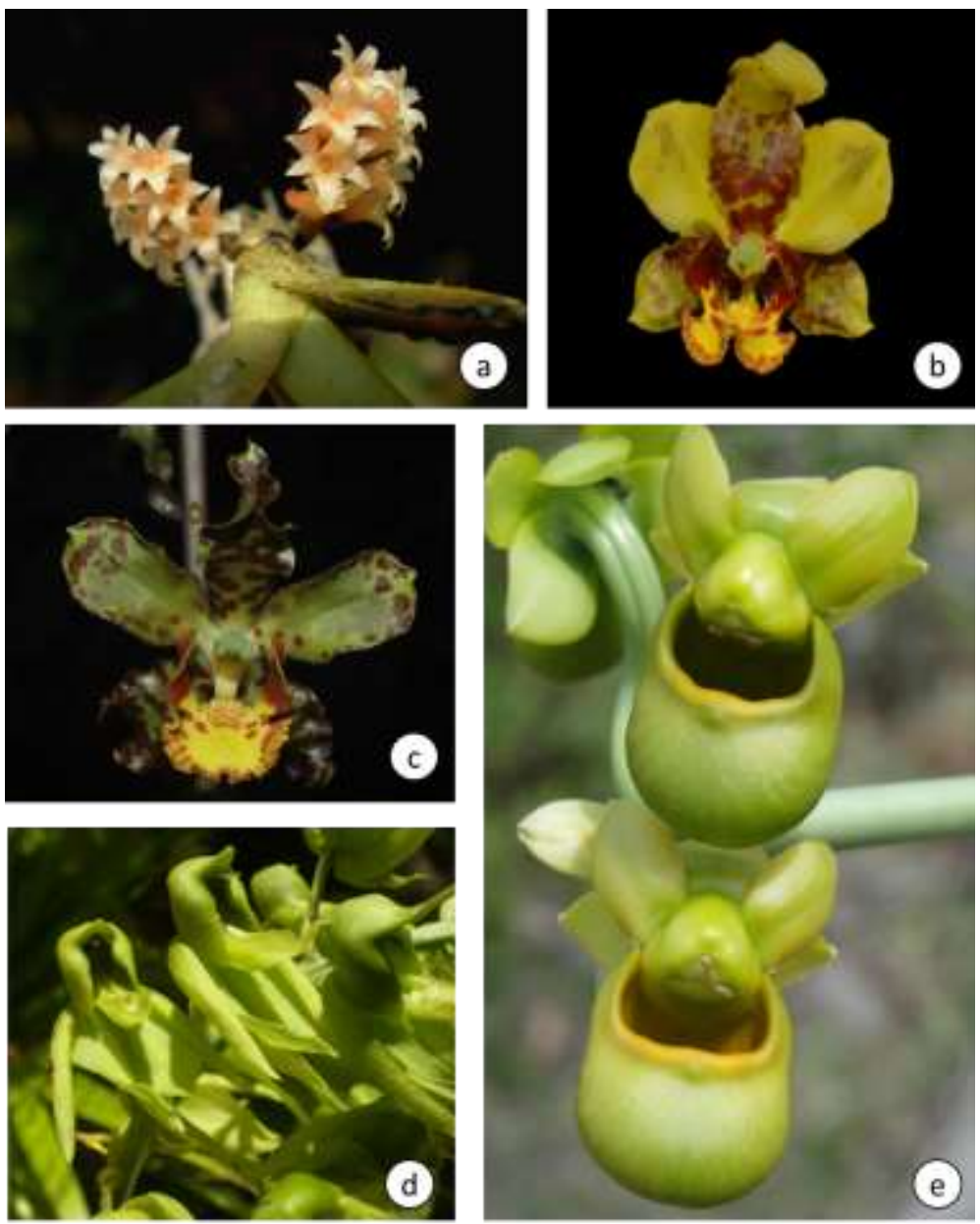
Rubens Teixeira de Queiroz

Bartolomeu Israel de Souza José João Lelis Leal de Souza Joseilsom Ramos de Medeiros Christianne Farias da Fonseca
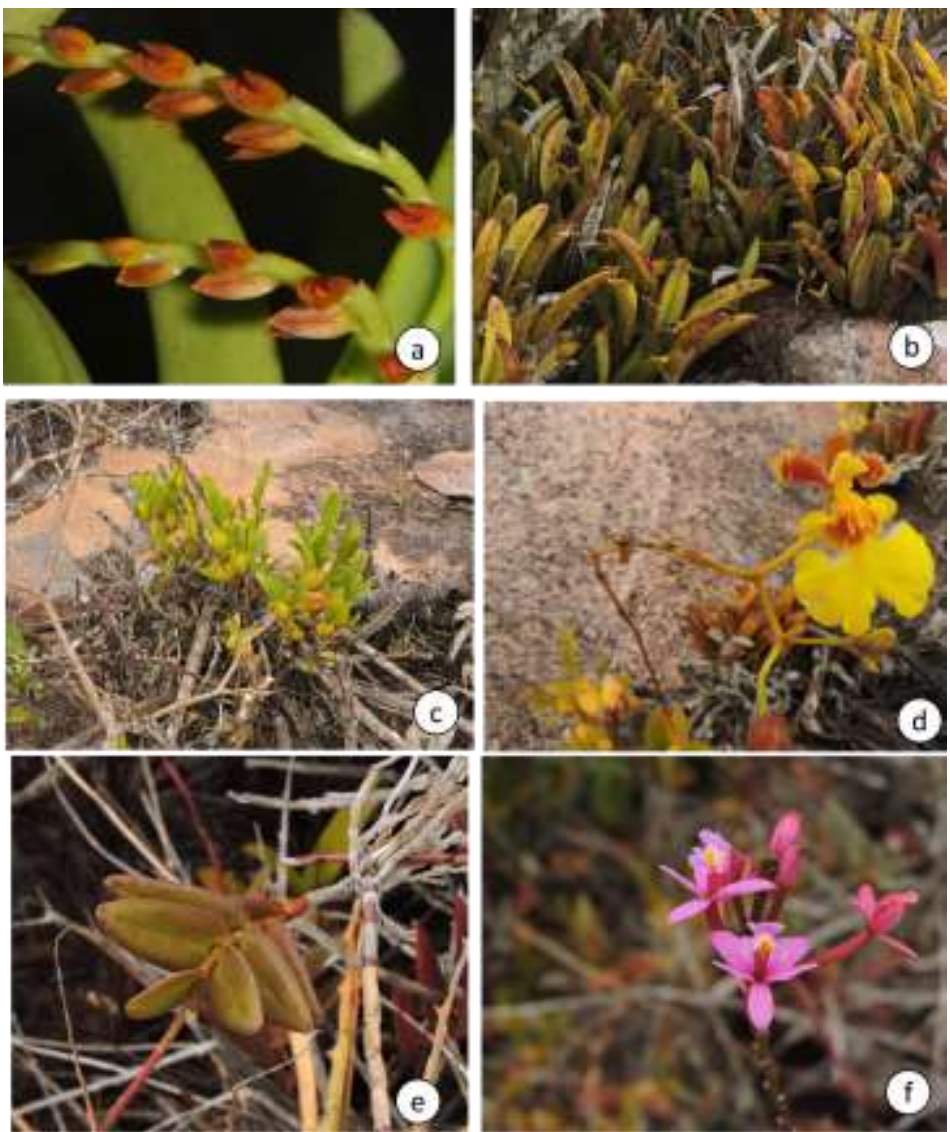

Figure IX - a-b - Acianthera ochreata (Lindl.) Pridgeon \& M.W.Chase; a-b - Coppensia flexuosa (Lodd.) Campacci; e-f - Epidendrum fulgens Brongn.
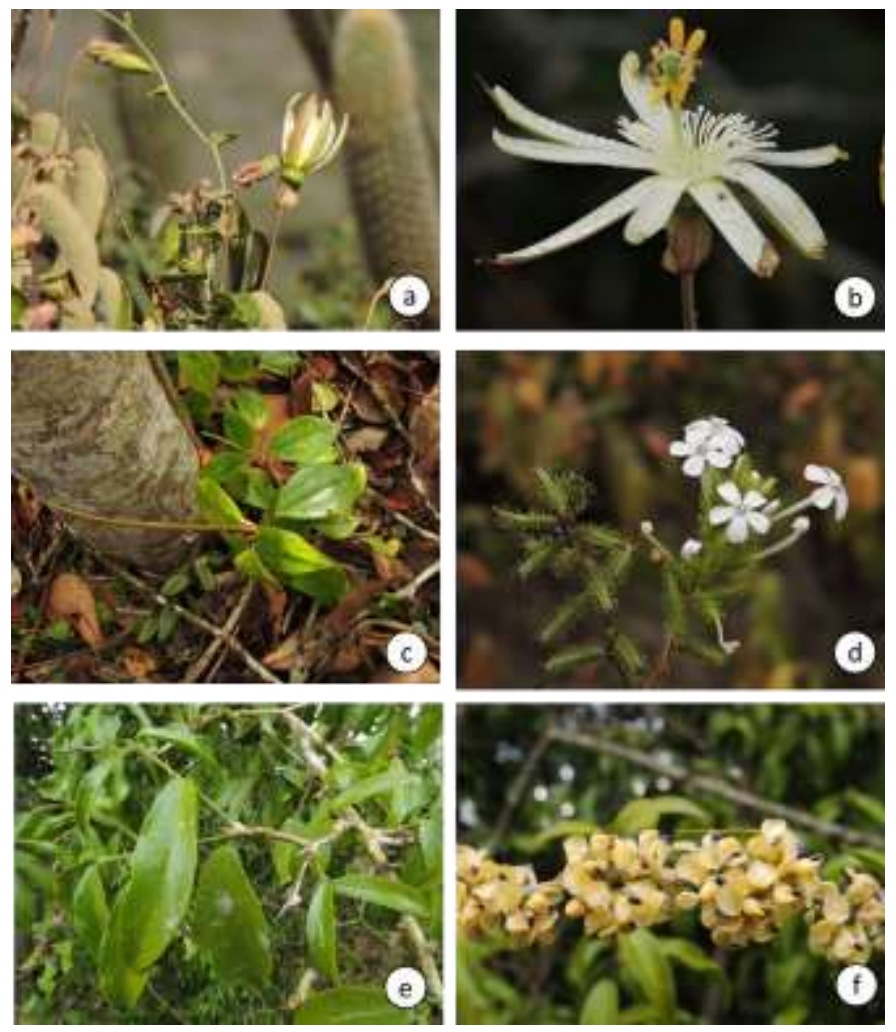
Rubens Teixeira de Queiroz

Bartolomeu Israel de Souza José João Lelis Leal de Souza Joseilsom Ramos de Medeiros Christianne Farias da Fonseca Eini Celly Morais Cardoso
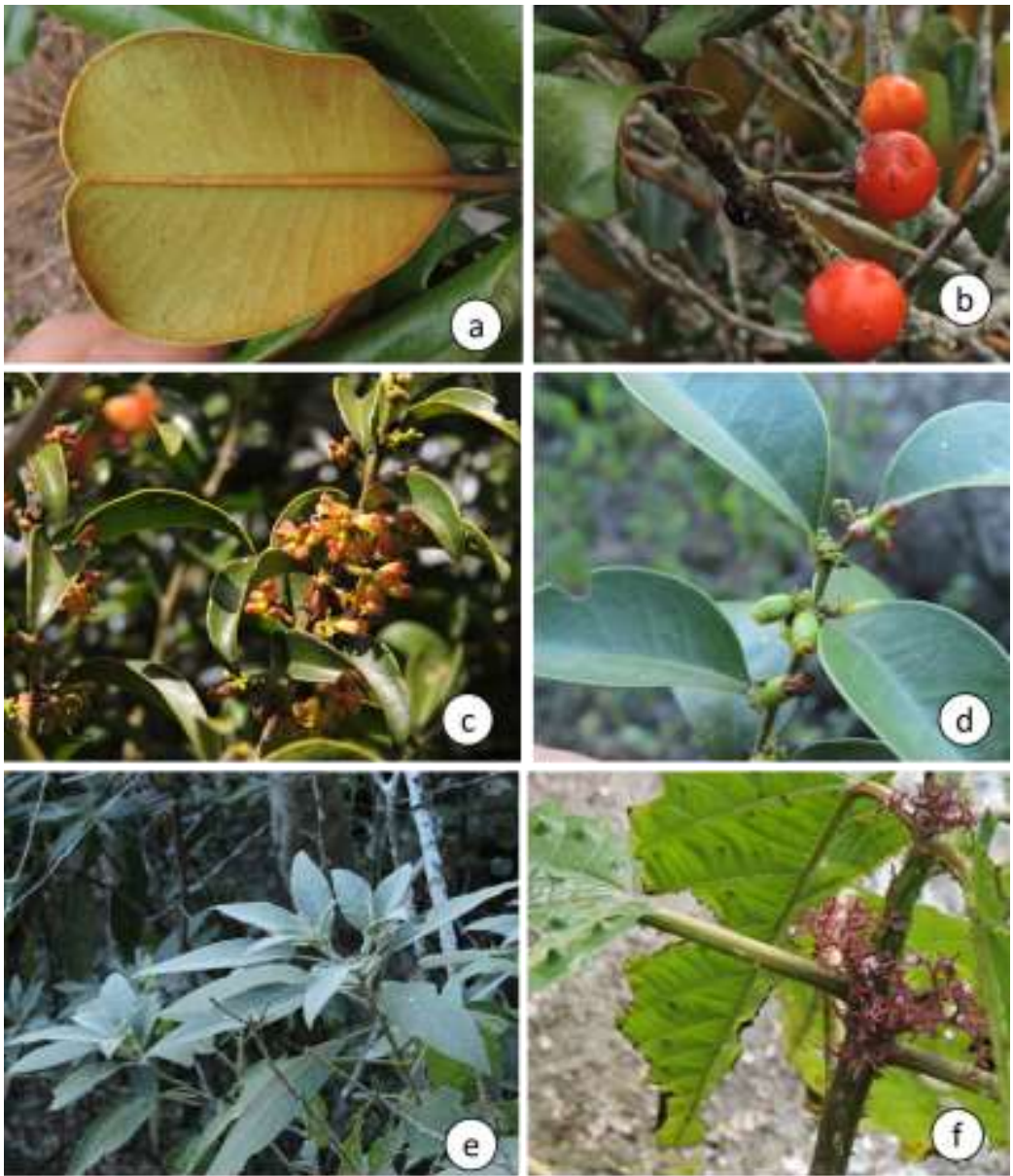

Figure XI - a-b - Manilkara rufula (Miq.) H.J.Lam;c-d. Schoepfia brasiliensis A.DC.; e - Solanum stipulaceum Willd. ex Roem. \& Schult.; $f$ - Urera nitida (Vell.) P.Brack

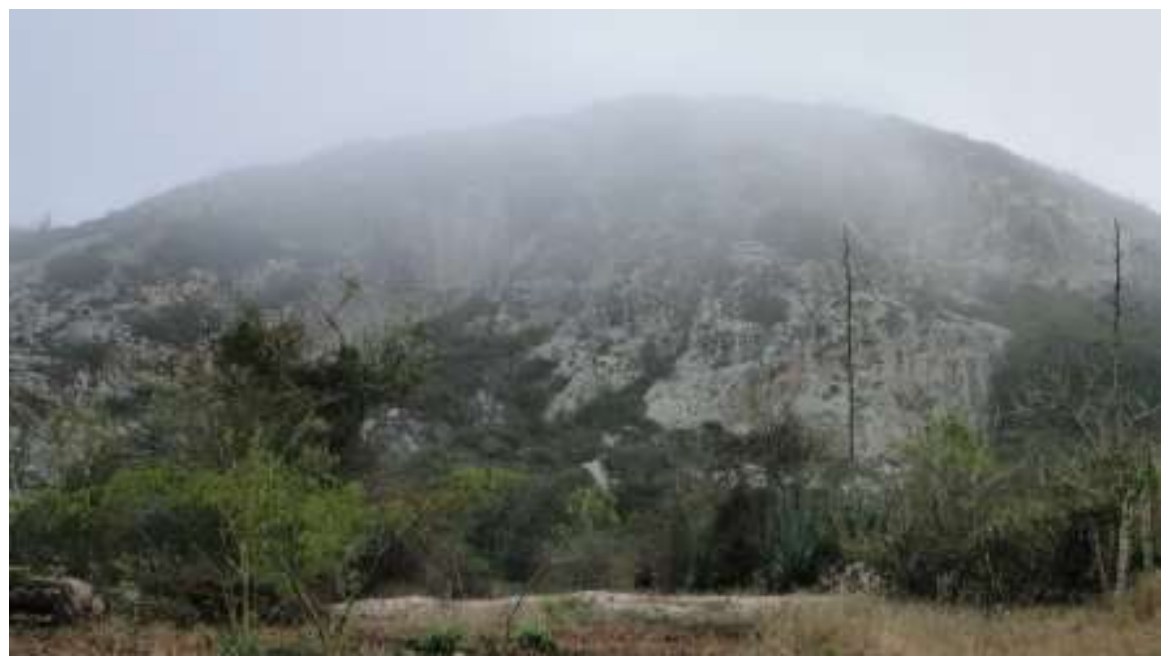

Figure XII. Landscape in study area.

Recebido em:30/06/2020

Aceito para publicação em:24/11/2020 